Universidad de Lima

Escuela de Posgrado

Maestría en Tributación y Política Fiscal

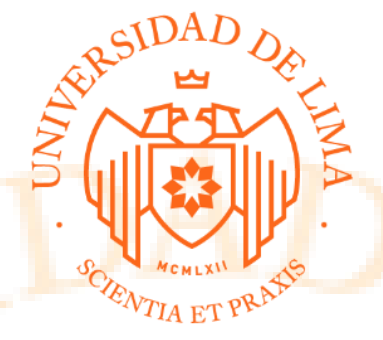

\title{
DESEMBOLSOS POSTERIORES (COSTOS) VINCULADOS CON EL RUBRO PROPIEDAD, PLANTA Y EQUIPO. TRATAMIENTO CONTABLE Y REPERCUSIÓN TRIBUTARIA
}

Trabajo de investigación para optar el Grado Académico de Maestro en

Tributación y Política Fiscal

Rosa Isabel Ortega Salavarría

Código 20042201

Asesor

Roberto José Casanova-Regis Albi

Lima - Perú

Febrero de 2020 


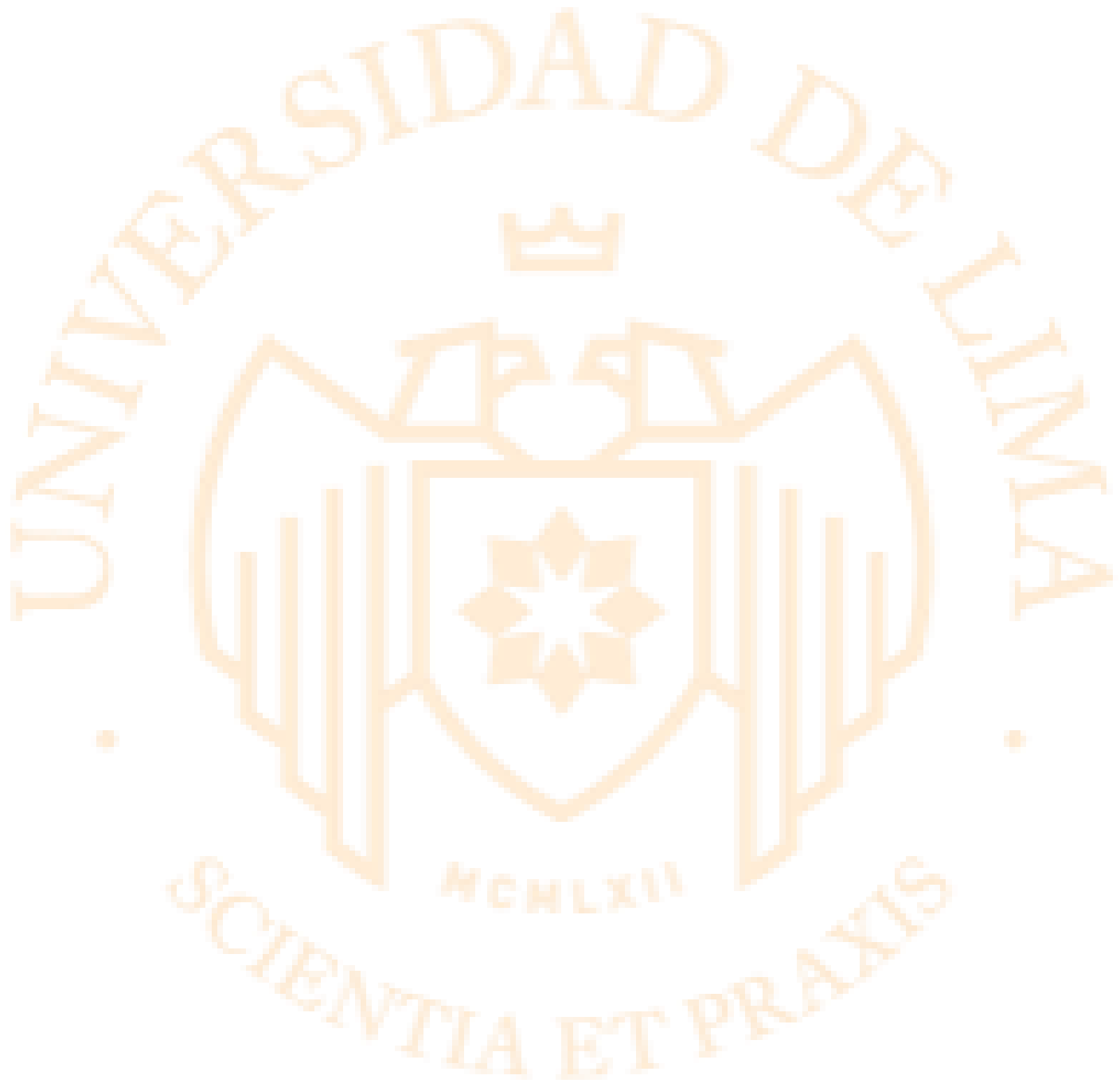




\title{
DESEMBOLSOS POSTERIORES (COSTOS) VINCULADOS CON EL RUBRO PROPIEDAD, PLANTA Y EQUIPO. TRATAMIENTO CONTABLE Y REPERCUSIÓN TRIBUTARIA
}

\author{
SUBSEQUENT EXPENDITURE (COSTS) \\ LINKED WITH THE PROPERTY, PLANT AND \\ EQUIPMENT HEADING. ACCOUNTING \\ TREATMENT AND TAX IMPACT
}




\section{TABLA DE CONTENIDO}

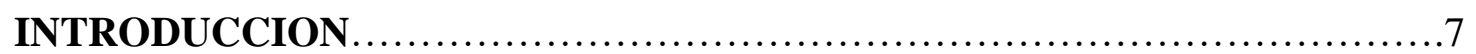

Capítulo I: Marco introductorio contable - tributario $\ldots \ldots \ldots \ldots \ldots \ldots \ldots \ldots \ldots$

1.1. Marco normativo contable aplicable en Perú...................................9

1.2. Impuesto a la Renta Corporativo.......................................... 11

1.2.1. Procedimiento de determinación del Impuesto a la Renta Corporativo............11

1.2.2. Costo computable.................................................... 13

1.2.3. Costos posteriores................................................... 14

1.2.4. Depreciación y Costos Posteriores............................................17

1.2.5. Transitoriedad de "mejoras permanentes" a "costos posteriores" ...............17

1.3. NIC 16: Propiedades, planta y equipo..................................... 18

1.3.1. Activo bajo el Marco Conceptual para la Información Financiera ................18

1.3.2. Propiedad, planta y equipo............................................. 19

1.3.3. Tratamiento de los desembolsos (i.e. costos o gastos) posteriores ..............23

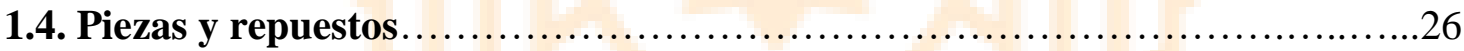

Capítulo II: Reconocimiento por componentes............................28

1.1. Criterio de reconocimiento de las partidas de Propiedad, planta y equipo.........28

1.2. ¿El reconocimiento por componentes implica que ya no se considere un

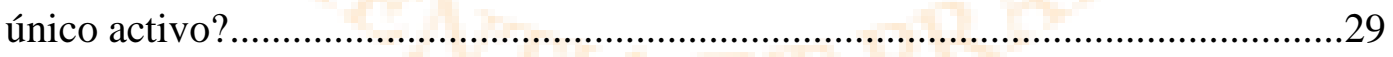

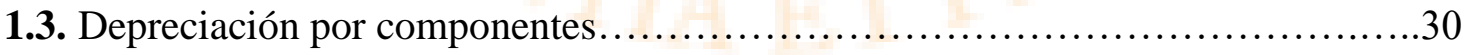

1.4. El reconocimiento por componentes y su incidencia tributaria..................31

Capítulo III: Costos posteriores.......................................... 33

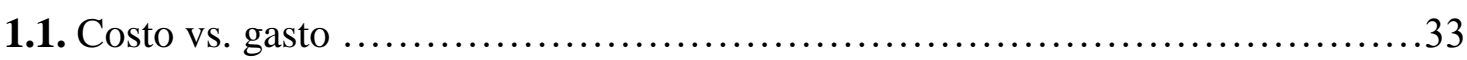

1.2. Tipos de costos posteriores........................................... 36

1.2.1. Adición, ampliación o expansión.......................................... 


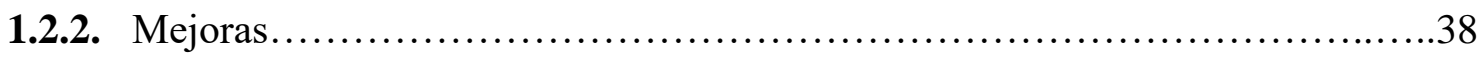

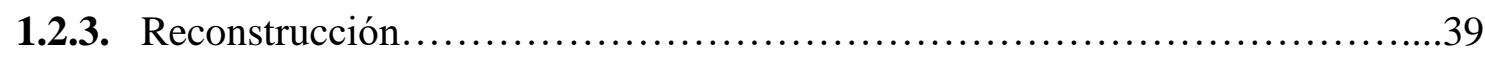

1.2.4. Reemplazos (o sustituciones) importantes............................40

1.2.5. Controversias tributarias........................................... 41

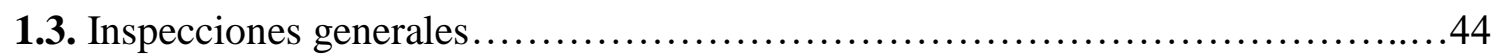

1.4. Tratamiento de los componentes de un activo que son sustituidos................45

1.4.1. Tratamiento contable................................................... 45

1.4.2. Análisis tributario.................................................. 48

1.5. Depreciación de costos posteriores.......................................50

1.5.1. Regulación tributaria y exposición de motivos.................................50

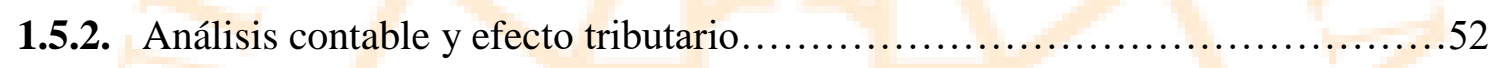

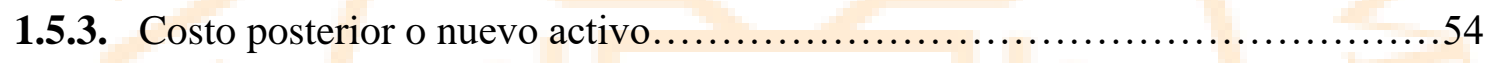

1.6. Análisis comparativo: Financiero vs. Tributario...............................55

Capítulo IV: CONCLUSIONES ........................................61

REFERENCIAS DE AUTORES E INSTITUCIONES ........................64

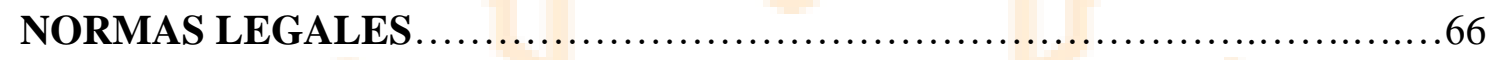

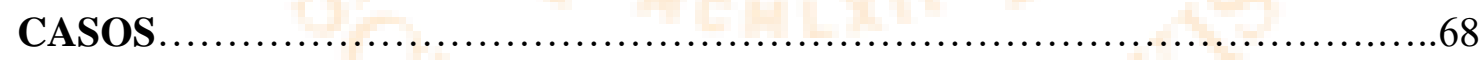

CARTAS E INFORMES DE SUNAT ...................................69

MARCO CONCEPTUAL Y NORMAS INTERNACIONALES DE

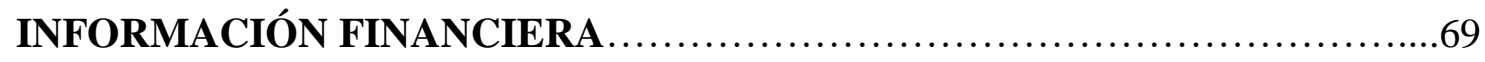




\section{INDICE DE FIGURAS}

Figura 1.1. Determinación del Impuesto a la Renta Corporativo......................12

Figura 1.2. Condiciones para el reconocimiento del rubro Propiedades, Planta y Equipo.........................................................

Figura 1.3. Criterio de reconocimiento del activo...............................29

\section{INDICE DE TABLAS}

Tabla 1.1. Nomenclatura y descripción de las subcuentas .23

\section{LISTA DE ACRÓNIMOS}

1. Comité de Normas Internacionales de Contabilidad (IASC)

2. Junta de Normas Internacionales de Contabilidad (IASB)

3. Consejo Normativo de Contabilidad (CNC)

4. Normas Internacionales de Contabilidad (NIC)

5. Normas Internacionales de Información Financiera (NIF)

6. Ley del Impuesto a la Renta (LIR)

7. Plan Contable General Empresarial (PCGE)

8. Principios de Contabilidad Generalmente Aceptados (PCGA)

9. Principios de Contabilidad aplicados en los Estados Unidos de Norteamérica (USGAAP)

10. Propiedades, Planta y Equipo (PPE)

11. Reglamento de la Ley del Impuesto a la Renta (RLIR)

12. Superintendencia del Mercado de Valores (SMV)

13. Superintendencia Nacional de Aduanas y Administración Tributaria (Sunat)

14. Texto Único Ordenado de la Ley del Impuesto a la Renta (TUO LIR) 


\section{RESUMEN}

El presente trabajo de investigación, se centra en el rubro Propiedad, planta y equipo y en forma específica en los desembolsos posteriores en los que se incurren durante la vida útil del activo, ello dado que es uno de los tópicos que generan mayor dificultad para identificar si califican como costo o gasto y a nivel tributario, se generan frecuentemente controversias entre los contribuyentes y la Administración Tributaria, respecto al tratamiento que corresponde otorgarles.

Al respecto, dado que la Ley del Impuesto a la Renta establece una remisión expresa a las normas contables para la calificación de "costos posteriores"; se exponen los requerimientos previstos en las NIIF sobre este rubro y se complementa con el análisis y casos prácticos desarrollados en la doctrina contable que permiten apreciar la aplicación de juicios, criterios de valor y estimaciones para reconocer y medir el activo.

En atención al análisis efectuado se concluye que, si bien la Ley del Impuesto a la Renta efectúa una remisión expresa a las normas contables, ello no implica que se desnaturalicen los principios rectores del impuesto a la renta, como es la prohibición del uso de estimaciones. A tal efecto, se muestra un cuadro consolidado que permite apreciar según supuestos específicos de costos posteriores las diferencias que se producirían entre el tratamiento financiero vs. el tratamiento tributario.

Palabras clave: Costos posteriores / NIC 16 / remisión expresa / Costo vs. gasto / Activo Fijo 


\begin{abstract}
The following research work, focuses on the Property, plant and equipment and specifically about the subsequent disbursements which incur throughout the useful life of the asset, it since is one of the topics which generates major difficulty in identifying if they qualify as cost or expense and at a tributary level, it often generates disputes between the taxpayers and the Tributary Administration, according to the treatment that confers to each of them.
\end{abstract}

About it, since the Law on Income Tax establishes an express remission to the accounting rules for the classification of the "subsequent costs"; it is exposed the expected requirements in the IFRS about this topic and they are complemented by the analysis and practical cases developed in the accounting doctrine which allows to appreciate the application of judgments, value criteria and approximations to recognize and measure the asset.

Based on the analysis carried out, it is concluded that, although the Law on Income Tax accomplishes an express remission to accounting standards, this doesn't imply that the guiding principles of income tax are distorted, such as the prohibition of the use of estimates. For this purpose, it is showing a consolidated chart which, according to specific assumptions of subsequent costs it allows to appreciate the differences that would be produced between the financial treatment vs. the tributary treatments.

Key Words: Subsequent costs/ IAS 16/ express remission/ Cost vs. expense/ Fixed asset 


\section{INTRODUCCIÓN}

En el ámbito empresarial, uno de los temas que genera frecuentemente controversia entre los contribuyentes (la Superintendencia Nacional de Aduanas y Administración Tributaria (Sunat) y el Tribunal Fiscal) corresponde al tratamiento aplicable a los desembolsos posteriores vinculados con el rubro de activo fijo con las consecuentes contingencias tributarias que ello podría originar. Para resolver la controversia, el Tribunal Fiscal, además de considerar el tratamiento previsto en la legislación del Impuesto a la Renta, recurre a las Normas Internacionales de Información Financiera (NIIF) y a la doctrina contable.

El presente trabajo de investigación tiene como finalidad argumentar sobre qué tratamiento tributario debe otorgarse a los "costos posteriores" vinculados con el activo fijo y considera la remisión específica hacia las normas contables realizada en la ley del Impuesto a la Renta. Dicha consideración valdrá para el entendimiento del concepto previamente planteado sin establecer parámetro o limitación alguna, lo que podría generar problemas interpretativos en la determinación del Impuesto a la Renta Corporativo.

A tal efecto, se desarrollará lo previsto en la NIC 16 (propiedades, planta y equipo) y en la doctrina contable, lo cual servirá de fundamento y análisis de los supuestos involucrados bajo dicho concepto. Complementariamente, la NIC 16 requiere el reconocimiento por componentes de un activo, denominado "componentización" y que conlleva -entre otros- a la realización de estimaciones cuando se producen desembolsos posteriores. En ese caso, se deberá analizar, con especial cuidado, el tratamiento tributario por otorgar y considerar las reglas generales aplicables para la determinación del Impuesto a la Renta Corporativo.

La casuística empresarial vinculada con desembolsos posteriores en propiedades, planta y equipo es diversa, lo cual privilegia, para efectos financieros (de acuerdo con las normas contables), la razonabilidad, la relevancia que involucra el criterio de materialidad o importancia relativa y representación fiel a efectos de establecer el tratamiento a otorgar para el reconocimiento y medición. Así, un desembolso que califica como activo podría, bajo el marco contable, válidamente ser tratado como un gasto. En nuestra opinión, dichos criterios 
no resultan aplicables para fines tributarios aun cuando se haya efectuado una remisión expresa a las normas contables.

El análisis se complementará con casuística jurisprudencial que permite revisar los fundamentos tributarios y contables considerados por el Tribunal Fiscal en virtud de los cuales emite el fallo respectivo. Se incluirán además los criterios vertidos por la Sunat.

De esta manera, se procura coadyuvar a probar nuestra hipótesis que para una adecuada conceptualización del concepto "costos posteriores" para fines tributarios debe aplicarse el marco normativo contable, pero sin que ello implique en lo absoluto distorsionar o desnaturalizar los criterios rectores del impuesto a la renta, en específico vinculados con la determinación del costo computable. 


\section{Capítulo I: MARCO INTRODUCTORIO CONTABLE - TRIBUTARIO}

En el presente capítulo, se analiza lo previsto en la legislación del impuesto a la renta respecto del costo computable y, en específico, sobre los costos posteriores bajo la fórmula legal de remisión expresa a las normas contables. A partir de dicha regulación, se aborda el tratamiento contable aplicable al rubro Propiedad, Planta y Equipo establecido en la NIC 16 con la finalidad de esbozar la definición de activo, las condiciones para su reconocimiento y el tratamiento contable por otorgar a los desembolsos posteriores.

\subsection{Marco normativo contable aplicable en Perú}

El artículo $223^{\circ}$ de la Ley General de Sociedades establece que "Los estados financieros se preparan y presentan de conformidad con las disposiciones legales sobre la materia y con principios de contabilidad generalmente aceptados en el país” (Ley N²6887, 1997).

La Resolución del Consejo Normativo de Contabilidad Nro. 013-98-EF/93.01, precisó en su Artículo $1^{\circ}$ que “(...) los principios de contabilidad generalmente aceptados comprenden substancialmente a las Normas Internacionales de Contabilidad (NIC) ${ }^{1}$, oficializadas mediante Resoluciones del Consejo Normativo de Contabilidad (...)” (1998).

Por tanto, en Perú se deben elaborar los estados financieros cumpliendo lo dispuesto en los principios de contabilidad generalmente aceptados (en adelante, PCGA), las Normas Internacionales de Información Financiera (en adelante NIIF) y supletoriamente los principios de contabilidad aplicados en los Estados Unidos de Norteamérica (en adelante USGAAP, por sus siglas en inglés) ${ }^{2}$. Obsérvese que, para la aplicación de una nueva NIIF o una nueva versión

\footnotetext{
${ }^{1}$ Actualmente Normas Internacionales de Información Financiera (NIIF).

${ }^{2}$ En la nota 1 del Informe de la SUNAT 075-2005-SUNAT/2B0000, se expresa que: Por su parte, la Resolución $N^{\circ}$ 13-1998EF/93.01, publicada el 23.7.1998, precisa que los Principios de Contabilidad Generalmente Aceptados a que se refiere el artículo antes citado comprende a las Normas Internacionales de Contabilidad (NICs), oficializadas mediante Resoluciones del Consejo Normativo de Contabilidad, (...).

Asimismo, la indicada Resolución precisa que por excepción y en aquellas circunstancias que determinados procedimientos operativos contables no estén normados por el Comité de Normas Internacionales de
} 
de éstas, se requiere la respectiva oficialización del Consejo Normativo de Contabilidad (en adelante $\mathrm{CNC}$ ).

Lo expuesto se ve sustentado, en el Artículo $6^{\circ}$ del Decreto Legislativo del Sistema Nacional de Contabilidad ${ }^{3}$, que a la letra señala:

\begin{abstract}
6.1 El Consejo Normativo de Contabilidad se encarga de la aprobación de las normas de contabilidad de aplicación en el sector privado y en las empresas públicas, en lo que corresponda.

6.2 Son funciones del Consejo Normativo de Contabilidad las siguientes:

(...)

2. Emitir resoluciones dictando y aprobando las normas de contabilidad para las entidades del sector privado y las empresas públicas, en lo que corresponda. (...) (2018)
\end{abstract}

Sin perjuicio de lo indicado en el párrafo anterior, en virtud del Artículo $30^{\circ}$ del TUO de la Ley de Mercado de Valores (Decreto Supremo Nro. 093-2002-EF, 2002) y el Artículo $1^{\circ}$ de la Resolución Nro. 102-2010-EF/94.01.14, las entidades comprendidas en el ámbito de supervisión de la Superintendencia del Mercado de Valores (en adelante, SMV) deberán aplicar las NIIF una vez que sean emitidas por la Junta de Normas Internacionales de Contabilidad (en adelante, IASB por sus siglas en inglés), vigentes internacionalmente, aun cuando no hayan sido oficializadas por el CNC.

En atención al marco normativo citado y tal como expresa Bravo, en Perú existe un Derecho Contable 5 , que debe servir - dada su especialidad - para interpretar conceptos técnicos, tales como activo o gasto, contenidos en la legislación del Impuesto a la Renta Corporativo. (2014, págs. 253-254)

Contabilidad (IASC), supletoriamente, se podrá emplear los Principios de Contabilidad aplicados en los Estados Unidos de Norteamérica (USGAAP).

${ }^{3}$ Aprobado por D. Leg. 1438, publicado el 16 de setiembre de 2018.

4 Publicada el 19 de octubre 2010

${ }^{5}$ Cabe mencionar que utilizamos el término Derecho Contable conforme este es entendido en el ámbito contable tributario sin pretender señalar con su uso que el mismo tiene la condición de fuente de Derecho en sentido estricto. 
En línea con dicha conclusión, apreciamos que, para fines tributarios, la interpretación de los conceptos contables debe fundamentarse en las NIIF que hayan sido oficializadas por la respectiva resolución del $\mathrm{CNC}$, en especial cuando dichos conceptos contables son “juridizados” a través de su incorporación en la legislación tributaria por expresa remisión ${ }^{6}$ de una norma legal.

A mayor abundamiento, citamos lo previsto en la segunda disposición complementaria final del decreto supremo 339-2018-EF respecto de la versión de la NIIF 15 que corresponde aplicar para efectos del devengo tributario a partir del ejercicio 2019: "La versión de la NIIF 15 a utilizarse es la oficializada mediante Resolución del Consejo Normativo de Contabilidad No 002-2018-EF/30” (Decreto Supremo 339-2018-EF, 2019).

\subsection{Impuesto a la Renta Corporativo}

\subsubsection{Procedimiento de determinación del Impuesto a la Renta Corporativo}

En virtud de lo regulado, en el Texto Único de la Ley del Impuesto a la Renta (en adelante TUO LIR) (2004) y su Reglamento (en adelante RLIR) ${ }^{8}$, el proceso para la determinación del Impuesto a la Renta Corporativo parte del reconocimiento del ingreso bruto, del cual se deducen los costos a efectos de determinar la renta bruta, de la cual se restan los gastos con la finalidad de obtener la renta neta o base imponible gravada con el $29.5 \%$ por concepto de Impuesto a la Renta Corporativo.

La renta bruta, en virtud del Artículo $20^{\circ}$ del TUO LIR, está constituida en el caso de la enajenación de bienes (tangibles e intangibles) por la diferencia entre el ingreso y el costo computable de los bienes enajenados, que comprende los costos iniciales y los costos posteriores.

\footnotetext{
${ }^{6}$ Ejemplos claros de dicha remisión por ejemplo son los Artículos $41^{\circ}$ y $57^{\circ}$ de la Ley del Impuesto a la Renta que se refieren al concepto financiero de “Costos Posteriores” y “Devengo" para el caso de enajenación de bienes, respectivamente.
}

${ }^{7}$ Aprobado por el D.S. Nro. 179-2004-EF y normas modificatorias

${ }^{8}$ Aprobado por D.S. Nro. 122-1994-EF y normas modificatorias 
Sobre la base del procedimiento de determinación antes indicado, la Ley del Impuesto a la Renta en su Artículo $41^{\circ}$ establece que "los costos incurridos respecto de un bien que ha sido afectado a la generación de rentas gravadas (...) deben ser reconocidos como costo según lo dispuesto en las normas contables" (2004). Dicho mandato implica de manera general que el "costo posterior" debe ser recuperado ${ }^{9}$ como gasto a través del cargo por depreciación. Sin embargo, el reconocimiento y medición de los costos posteriores, en aplicación de la norma financiera, tendrán el mismo tratamiento para determinar el costo computable, el cual genera diferencias entre el tratamiento financiero y fiscal aplicable a los "costos posteriores".

Figura 1.1.

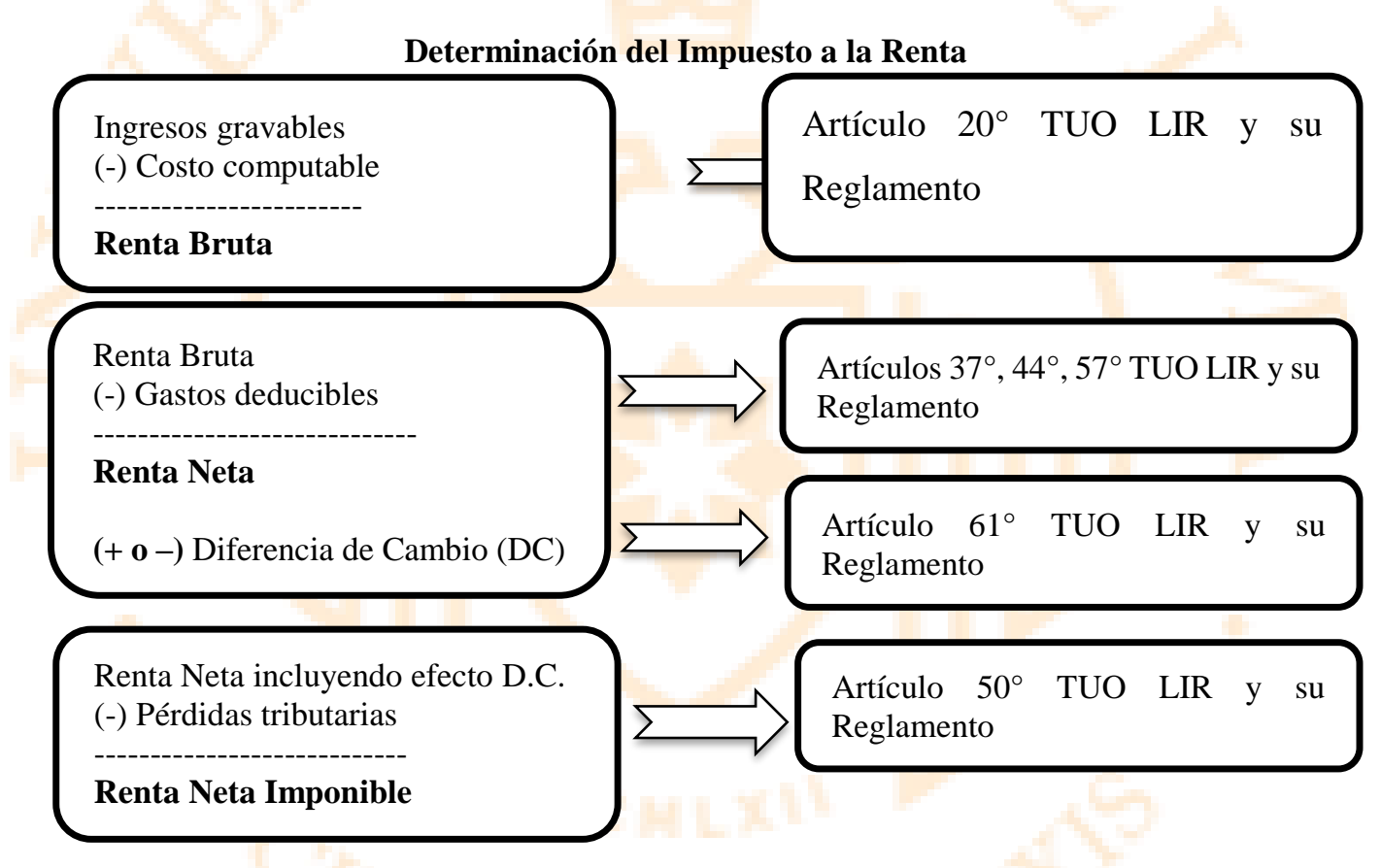

Elaboración propia

Sin perjuicio del procedimiento antes señalado, en virtud de lo previsto en el Artículo $33^{\circ}$ del RLIR y el proceso plasmado en la declaración jurada anual del impuesto a la renta para efectos prácticos, los operadores contables a partir del resultado contable obtenido bajo PCGA y NIIF efectúan los ajustes respectivos (adiciones y deducciones) para determinar la renta neta acorde a lo previsto en la regulación fiscal.

\footnotetext{
${ }^{9}$ Otras formas de recuperar la inversión en un activo y/o costo posterior es a través de su enajenación, desuso, obsolescencia o pérdida extraordinaria en todos los casos con cargo a la magnitud del Ingreso Bruto.
} 


\subsubsection{Costo computable}

El Artículo $20^{\circ}$ del TUO LIR dispone que:

La Renta Bruta está constituida por el conjunto de ingresos afectos al impuesto que se obtengan en el ejercicio gravable. Cuando tales ingresos provengan de la enajenación de bienes, la renta bruta estará dada por la diferencia existente entre el ingreso neto total proveniente de dichas operaciones y el costo computable de los bienes enajenados, siempre que dicho costo esté debidamente sustentado con comprobantes de pago. (2004)

El costo computable constituye, por tanto, el costo del activo enajenado que incide o afecta a resultados y en el caso de bienes depreciables o amortizables, el costo computable se disminuirá en el importe de las depreciaciones o amortizaciones admitidas tributariamente. Por ello, en el precitado Artículo $20^{\circ}$ se le conceptualiza como el costo de adquisición, costo de producción o construcción, o valor de ingreso al patrimonio y se efectúa en forma expresa la definición de dichas categorías.

Complementariamente, el literal “j” del Artículo $11^{\circ}$ del Reglamento, regula la aplicación supletoria de las normas contables y principios de contabilidad generalmente aceptados para determinar el costo computable y además que los conceptos tales como activo o depreciación no se encuentran propiamente definidos en la legislación fiscal. Asimismo, señala que dicha aplicación supletoria procederá en tanto no se oponga a la LIR y reglamento. 


\subsubsection{Costos posteriores}

En virtud del Artículo $20^{\circ}$ TUO LIR y el numeral 1 literal b) artículo 11 de su Reglamento, uno de los componentes que incrementa el costo computable corresponde a: "los costos posteriores incorporados al activo de acuerdo con las normas contables”.

De igual forma, el ítem “ii” literal “a” primer párrafo del Artículo 41 TUO LIR, para efectos del cálculo de la depreciación, define a los Costos Posteriores de la forma siguiente: "Los costos incurridos respecto de un bien que ha sido afectado a la generación de rentas gravadas y que, de conformidad con lo dispuesto en las normas contables, se deban reconocer como costo." (2004)

En concordancia con dicha regulación, el literal "e" del artículo $44^{\circ}$ TUO LIR prescribe que no resultan deducibles para determinar la renta neta, las sumas invertidas en la adquisición de bienes o costos posteriores incorporados al activo de acuerdo con las normas contables. Por tanto, dichas sumas o desembolsos (iniciales o posteriores) no podrán afectarse como gasto en un solo ejercicio, sino que incidirán en resultados vía depreciación.

Procede señalar que fue mediante el Decreto Legislativo $N^{\circ} 1112$ (2012) vigente a partir del ejercicio 2013, que se incorporó el concepto de “costos posteriores”, el cual sustituyó al término "mejoras de carácter permanente" en todos los artículos de la LIR en que se efectuaba dicha referencia.

La exposición de motivos del Decreto Legislativo $\mathrm{N}^{\circ} 1112$ propuso la modificación normativa debido a que "La NIC 16 Inmuebles, maquinaria y equipo ya no hace mención alguna al concepto de mejoras, sino que actualmente hace referencia a los costos posteriores, estableciendo que éstos se reconocerán como parte del costo de los bienes inmuebles, maquinaria y equipo siempre que cumplan con los criterios generales que ella dispone".

A mayor abundamiento, en dicha exposición de motivos se cita a los párrafos 7 y 10 de la NIC 16 que prescriben el tratamiento de los costos posteriores para fines contables. 
De acuerdo con el análisis efectuado, se observa que la modificatoria tuvo como sustento adecuar su terminología a las normas contables, específicamente, la NIC 16: propiedad, planta y equipo, que ya no utilizaba el término mejoras. Para dicho efecto, se realizó una remisión expresa a las normas contables.

En nuestra opinión, el sustento presentado en la exposición de motivos del Decreto Legislativo 1112 no consideró a detalle los diferentes supuestos que pueden presentarse bajo las normas, así como doctrina contable y que, en determinadas circunstancias, podría resultar opuesto o contradictorio con el marco previsto en la legislación del impuesto a la renta.

Así, en general debe observarse que la LIR y su reglamento no admiten para determinar si un desembolso es costo o gasto, la aplicación de juicios o criterio profesional, la aplicación de la materialidad bajo la característica de relevancia, así como representación fiel ni la aplicación de estimaciones de valor.

En la misma línea, en la Casación 5476-2016 LIMA $^{10}$ respecto del costo computable se señala que

9.17 Al respecto, debe precisarse que para preparar los estados contables de una empresa, los contribuyentes pueden deducir todos los costos en que incurra la empresa a fin de obtener sus estados contables y utilidades netas; sin embargo, a nivel tributario no sucede lo mismo, debido a que cada operación registrada o deducida originará un mayor o menor impuesto, debiéndose deducir solamente aquellos costos y gastos que permita la norma, así como en la forma que la ley lo establece, pues su registro u omisión tendrá efectos en la determinación de los impuestos a pagar (énfasis agregado). (Casacion, 2017)

Acorde a esta premisa inicial, se abordará en el capítulo III: Costos posteriores los supuestos o tipos más recurrentes de desembolsos posteriores desarrollados en la doctrina y su tratamiento contable que corresponde otorgarle, para luego discernir sobre el tratamiento tributario que debería corresponderle.

Procede indicar que, no obstante, en la modificatoria producida, el Tribunal Fiscal para resolver casos en controversia sobre esta materia respecto de ejercicios gravables desde el 2013, en algunas resoluciones aún sigue sustentando su criterio en la versión de la NIC 16

\footnotetext{
${ }^{10}$ De fecha 6 de octubre 2017 y publicada en el Diario Oficial “El Peruano” el 31 de agosto 2018.
} 
(revisada en 1998) y analiza, por ende, si el desembolso constituye o no una "mejora de carácter permanente", supuesto que no se condice con la legislación tributaria vigente en dicho ejercicio. Así, a título ilustrativo citamos la RTF 10313-11-2018 (13.12.2018) y que analiza reparos formulados por Sunat respecto del impuesto a la renta del ejercicio 2015:

Que al respecto, cabe señalar que de acuerdo con la Norma Internacional de Contabilidad - NIC $16,(\ldots)$ que los desembolsos posteriores sobre inmuebles, maquinaria y equipo solo se reconocer como activo cuando mejoran la condición del activo más allá del rendimiento estándar originalmente evaluado, como por ejemplo, la extensión de su vida útil, el mejoramiento sustancial en la calidad de la producción obtenida o la reducción de los costos de producción.

Que de acuerdo con el criterio establecido por este Tribunal (...), el elemento que permite distinguir si un desembolso relacionado a un bien del activo fijo preexistente constituye un gasto por mantenimiento o reparación, o una mejora de carácter permanente que debe incrementar su costo computable, es el beneficio obtenido con relación al rendimiento estándar originalmente proyectado; así, si el desembolso origina un rendimiento mayor, deberá reconocerse como activo, (...)

Que de lo expuesto, se puede señalar que las operaciones observadas por la Administración corresponden (...), y por la construcción y/o remodelación de la infraestructura que corresponde a las aulas del local de la recurrente que es un colegio (bien inmueble), desembolsos que originan un rendimiento y duración mayor, por lo que también debieron reconocerse como activo fijo, pues acompañaran toda la vida al bien inmueble (...). (RTF, 2018)

Cabe señalar que, en el caso citado, compartimos el criterio del Tribunal Fiscal respecto de que dichos desembolsos constituyen activo, pero bajo la calificación de "costo posterior" según lo requerido por la NIC 16 vigente en el ejercicio gravable 2015 y que resulta aplicable para fines tributarios según lo expuesto previamente. Procede indicar que la administración tributaria al formular los argumentos que sustentan su reparo sí efectúa la referencia a la NIC 16 vigente en dicho ejercicio. 


\title{
1.2.4. Depreciación y costos posteriores
}

En el Artículo $41^{\circ}$ TUO LIR, se determina el procedimiento que debe realizarse para calcular la depreciación tributaria deducible en el caso de activos fijos, que considere tanto los costos iniciales incurridos con anterioridad al inicio de la afectación del bien a la generación de rentas gravadas (costo de adquisición, producción o construcción, o valor de ingreso al patrimonio) como los costos posteriores.

A tal efecto se considerará:

$1^{\circ}$ Sumar los costos iniciales y los costos posteriores

$2^{\circ}$ A dicho resultado se le aplica el porcentaje anual de depreciación (en el caso de edificios y construcciones) o el porcentaje máximo de depreciación

$3^{\circ} \mathrm{El}$ importe resultante será el monto deducible (para edificios y construcciones) o el máximo deducible (para otros tipos de bienes).

\author{
DEPRECIACIÓN (deducible o máxima deducible) \\ $\%$ depreciación tributario x (Costo inicial + costos posteriores)
}

Sin perjuicio de dicho procedimiento, la deducción en el último ejercicio podrá ser menor, pues corresponderá al valor del bien que quede por depreciar.

En el numeral 1.5 del capítulo III se analiza a detalle sobre este tópico.

\subsubsection{Transitoriedad de "mejoras permanentes" a "costos posteriores"}

Acorde a lo desarrollado en los numerales previos, a continuación, presentamos en forma gráfica la transitoriedad en la legislación del impuesto a la renta respecto de la regulación de mejoras permanentes a costos posteriores. 
NIC 16: Costos posteriores de PPE - Aplicable en el Perú 2005- 2006

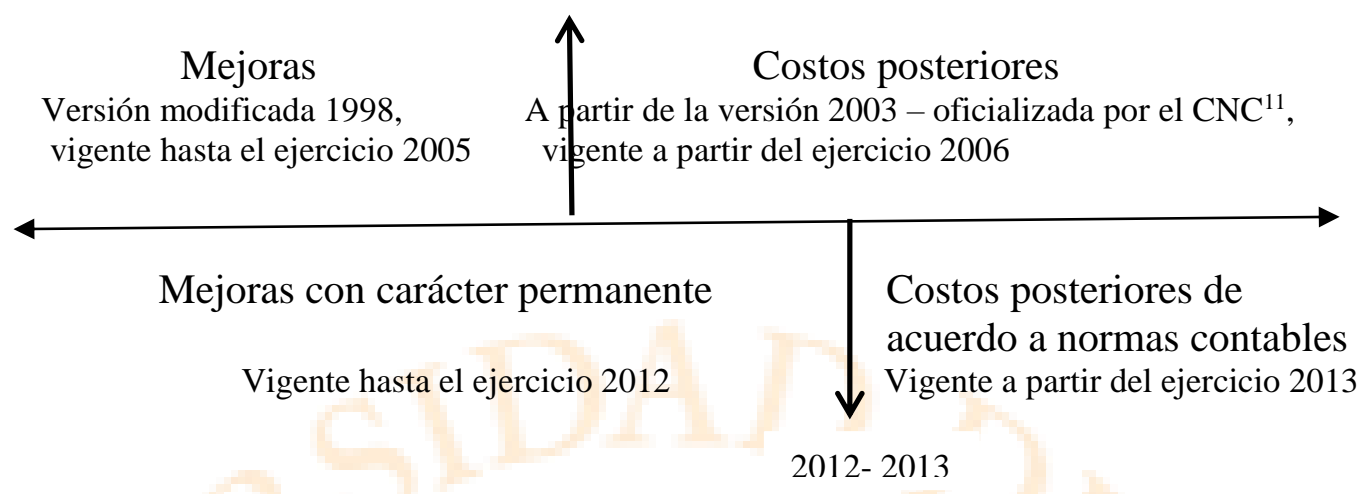

Legislación del impuesto a la renta - Costo computable

La legislación del impuesto a la renta no ha precisado la versión de la norma contable que corresponde considerar, es decir, aquella que se encontraba vigente en el ejercicio 2012 cuando se publica el Decreto Legislativo 1112, en el ejercicio 2013 cuando entra en vigor la modificatoria o la vigente en cada ejercicio gravable en que corresponde determinar el impuesto a la renta.

$\mathrm{Al}$ respecto, dado que ello no ha sido regulado en forma expresa, consideramos que se debe aplicar la versión vigente en cada ejercicio gravable en que corresponde determinar el impuesto a la renta. A mayor abundamiento en la RTF 3339-1-2019 (5.4.2019) al citar a la NIC 16, se efectúa la cita siguiente: "Versión 2003, vigente en el ejercicio fiscalizado. Oficializada por el Consejo Normativo de Contabilidad a través de la Resolución № 0342005-EF/93.01, publicada el 2 de marzo de 2005”. (RTF, 2019)

\subsection{NIC 16: Propiedades, planta y equipo ${ }^{12}$}

\subsubsection{Activo bajo el Marco Conceptual para la Información Financiera}

${ }^{11}$ Resolución del Consejo Normativo de Contabilidad 034-2005-EF/93.01

${ }^{12}$ La versión 2019 de la NIC 16, fue oficializada mediante Resolución del Consejo Normativo de Contabilidad No 003- 2019-EF/30, publicada el 21.09.2019 


\section{a) Breve síntesis}

El Marco Conceptual para la Preparación de Información Financiera ${ }^{13}$ describe el objetivo y los conceptos para los informes financieros de propósito general. El 29 de marzo 2018, el IASB aprobó la nueva versión del citado Marco Conceptual - en adelante Marco Conceptual 2018 - que deberá ser utilizado por las empresas a partir del 01 de enero $2020^{14}$ y sustituye al Marco Conceptual 2010.

El Marco Conceptual 2018 se ha oficializado para su aplicación en Perú mediante la Resolución del Consejo Normativo de Contabilidad No 002-2018-EF/30.

b) Definición de Activo

Los párrafos 4.3 y 4.4 del Marco Conceptual 2018 conceptualizan al elemento "Activo" de acuerdo con lo siguiente:

4.3. Un activo es un recurso económico presente controlado por la entidad como resultado de sucesos pasados. $\mathrm{V}$

4.4. Un recurso económico es un derecho que tiene el potencial para producir beneficios económicos"

Por tanto, el "Activo" al constituir un recurso económico, queda definido en concreto como un derecho. Además, el concepto de recurso económico comprende a la capacidad para que se produzcan los beneficios económicos.

\subsubsection{Propiedad, planta y equipo}

\section{a) Definición}

El párrafo 6 de la NIC 16: Propiedades, planta y equipo - en adelante NIC 16 - define a este rubro como:

\footnotetext{
${ }^{13}$ No es una Norma Internacional de Información Financiera (NIIF)

${ }^{14}$ Se permite su aplicación anticipada.
} 
"Activos tangibles que:

(a) Posee una entidad para su uso en la producción o suministro de bienes y servicios para arrendarlos a terceros o para propósitos administrativos; y

(b) Se esperan usar durante más de un ejercicio."

Esta condición se vincula con el carácter de permanencia que ostentan los activos incorporados a este rubro y que coadyuva a su identificación.

Procede indicar que a los terrenos o edificios que se mantengan para obtener rentas (arrendarlos a terceros) o para apreciación del capital, o con ambos fines, les resulta aplicable la NIC 40: Propiedades de Inversión. No obstante, para fines tributarios si se encontraran comprendidos en el rubro "activo fijo" como edificaciones o construcciones.

Además, se encuentra fuera del alcance de la NIC 16, al considerar su naturaleza intrínseca y el uso previsto, los activos tangibles siguientes: (i) activos biológicos, regulados por la NIC 41: agricultura, salvo plantas productoras y (ii) activos mantenidos para su disposición o enajenación, y que se encuentran bajo lo previsto en la NIIF 5: activos no corrientes mantenidos para la venta y operaciones discontinuadas.

\section{b) Principio de reconocimiento}

En virtud de los párrafos 5.1, 5.6 y 5.7 del Marco Conceptual 2018, el reconocimiento alude a un proceso de incorporación en el estado de situación financiera o en el estado de resultados de una partida que cumpla la definición de uno de los elementos de los estados financieros como es el caso de un activo que satisface, además, los criterios para su reconocimiento.

En concordancia con dicho requerimiento, en el párrafo 7 de la NIC 16 se instaura el principio de reconocimiento que prescribe los criterios de obligatorio cumplimiento para reconocer un bien en el rubro "Propiedad, planta y equipo" tanto para el reconocimiento inicial como cuando se incurran en desembolsos posteriores: "El coste de un elemento de 
propiedades, planta y equipo se reconocerá como activo sí, y solo si: (a) sea probable que la entidad obtenga los beneficios económicos futuros derivados de este; y (b) el costo del elemento puede medirse con fiabilidad."

Cabe resaltar que una condición de reconocimiento es la probabilidad para la empresa de obtener los beneficios económicos vinculados al activo y, por ende, que asuma los riesgos asociados a los mismos. Ello implica que la propiedad no es relevante o condicionante, por ello también se reconocen, en este rubro, aquellos desembolsos incurridos por el arrendatario en bienes arrendados en tanto cumplan las condiciones enunciadas.

Otal y Serrano expresan respecto de la prevalencia de los beneficios económicos que: “(...) desplaza el requisito de la disposición de la propiedad del bien a favor de la transferencia de los riesgos y ventajas asociados al disfrute y, por ende, al control del mismo. (...)" (Otal \& Serrano, 2006, pág. 3).

\section{c) Potencial de producir beneficios económicos}

El beneficio económico involucrado con este tipo de bienes, por lo general, se vincula con el potencial que va a contribuir directa o indirectamente a generar flujo de efectivo o evitar salidas de efectivo.

Así, los beneficios económicos fluyen a la empresa en la oportunidad que se usa el activo solo o en combinación con otros para producir bienes o proporcionar servicios. Adicionalmente, podrían fluir los beneficios económicos producto de la transferencia o disposición del activo.

Un supuesto sui géneris, relacionado con la obtención de beneficios económicos adicionales en forma indirecta, lo encontramos en el párrafo 11 de la NIC 16 que aborda sobre determinados activos que se adquieren (costos iniciales) o se adecuan (desembolsos posteriores) por razones específicas (por ejemplo, seguridad o de índole medioambiental) y con la finalidad de obtener beneficios económicos derivados del resto de los activos. 
Respecto del supuesto desarrollado en el párrafo anterior, citamos el ejemplo presentado en el párrafo 11 de la NIC 16:

\begin{abstract}
Por ejemplo, una industria química puede tener que instalar nuevos procesos de fabricación para cumplir con la normativa medioambiental relativa a la producción y almacenamiento de productos químicos, reconociendo entonces como parte de propiedades, planta y equipo las mejoras efectuadas en la planta, en la medida que sean recuperables, puesto que sin ellas la entidad quedaría inhabilitada para producir y vender esos productos químicos.
\end{abstract}

Para la evaluación que debe realizar la empresa sobre el potencial del activo de producir beneficios económicos, se debe considerar la evidencia disponible en la oportunidad en que se efectúa dicho análisis.

\title{
d) Clasificación del rubro propiedad, planta y equipo
}

Kieso y Weygandt efectúan una clasificación a nivel de tres rubros de este elemento: “Terrenos, Edificios y Equipo'. Respecto de este último concepto, señala que en contabilidad el término "equipo" incluye el equipo para entrega de mercancías, equipo de oficina, mobiliario y accesorio, equipo de fábrica, y otros activos fijos similares. (Kieso \& Weygandt, 1999, pp. 554-555)

Por su parte, el Plan Contable General Empresarial ${ }^{15}$, en la cuenta 33: Propiedad, planta y equipo, prevé que se deben registrar los bienes que cumplan con la definición efectuada por la NIC 16. Para dicho efecto, se crean subcuentas específicas para distinguir su registro contable según el destino o uso de los bienes, o según su naturaleza.

Tabla 1.1. Nomenclatura y descripción de las subcuentas

\begin{tabular}{|l|l|}
\hline Subcuenta (tipo de activo) & \multicolumn{1}{c|}{ Descripción } \\
\hline 330 Planta productora & $\begin{array}{l}\text { Corresponde a los activos biológicos vivos que: se utilizan en el } \\
\text { suministro de productos agrícolas, se espera produzcan durante }\end{array}$ \\
\hline
\end{tabular}

${ }^{15}$ A través de la Resolución No 002-2019-EF/30 (24.05.2019) se aprueba el Plan Contable General Empresarial (PCGE) - modificado 2019 - vigente a partir del 01.01.2020. 


\begin{tabular}{|l|l|}
\hline 331 Terrenos & $\begin{array}{l}\text { más de un periodo, y la probabilidad de su venta como producto } \\
\text { agrícola es remota. }\end{array}$ \\
\hline 332 Edificaciones & $\begin{array}{l}\text { Comprende el valor de los terrenos destinados al uso de la entidad; } \\
\text { pueden ser urbanos o agrícolas. }\end{array}$ \\
\hline $\begin{array}{l}\text { 333 Maquinarias y equipos } \\
\text { de explotación }\end{array}$ & $\begin{array}{l}\text { Incluye aquellos que están destinados al proceso productivo o al } \\
\text { uso administrativo. También se incluyen como parte de esta } \\
\text { subcuenta, las mejoras en locales arrendados. }\end{array}$ \\
\hline Corresponde a las que se utilizan en el proceso productivo \\
\hline 335 Muebles y enseres & $\begin{array}{l}\text { Comprende el mobiliario y los enseres utilizados en todos los } \\
\text { procesos empresariales, incluyendo el administrativo. }\end{array}$ \\
\hline 336 Equipos diversos & $\begin{array}{l}\text { Incluye los equipos no utilizados directamente en el proceso } \\
\text { productivo, además de aquellos para el soporte administrativo. }\end{array}$ \\
\hline $\begin{array}{l}\text { 337 Herramientas } \\
\text { unidades de reemplazo }\end{array}$ & $\begin{array}{l}\text { Contiene herramientas de importancia material, y activos cuyo } \\
\text { propósito es sustituir a otros en uso. }\end{array}$ \\
\hline 338 Unidades por recibir & $\begin{array}{l}\text { Bienes de propiedad, planta y equipo, para los cuales se ha } \\
\text { incurrido en costos y que están pendientes de ingreso a la entidad. }\end{array}$ \\
\hline 339 Obras en curso & Bienes en proceso de construcción o montaje \\
\hline
\end{tabular}

\subsubsection{Tratamiento de los desembolsos (i.e. costos o gastos) posteriores}

\section{a) Condiciones para su tratamiento como activo}

Es frecuente en las empresas incurrir en desembolsos posteriores vinculados con los activos del rubro "Propiedad, planta y equipo" con la finalidad de mantener su potencial de producir beneficios económicos como sería su potencial de servicio o uso en la producción de bienes.

Sobre el particular, el párrafo 10 de la NIC 16 establece que "la entidad evaluará, de acuerdo con este principio de reconocimiento, todos los costos de propiedades, planta y equipo en el momento en que se incurre en ellos. Estos costos comprenden (...) los costos incurridos posteriormente para añadir, sustituir parte de o mantener el elemento correspondiente".

En atención a ello, los desembolsos posteriores incurridos en propiedades, planta y equipo serán reconocidos como activo solo si cumplen con las condiciones de reconocimiento previstas en el párrafo 7 de la NIC 16 y que han sido materia de análisis en el literal b) del numeral 1.3.2. Ello implica que los desembolsos posteriores calificarán como activos si 
cumplen las condiciones siguientes: (i) probabilidad de obtener beneficios económicos futuros y (ii) el costo se pueda medir fiablemente.

Los desembolsos posteriores, según su naturaleza o características, se podrán incorporar como parte del importe en libros de un activo existente como sería el supuesto de la sustitución de componentes o se considerarán como un activo nuevo.

Obsérvese que la NIC 16 no desarrolla criterios o condiciones específicas para reconocer los desembolsos posteriores como activo, sino que solo enuncia como requisito la aplicación del principio general de reconocimiento y en función del cual la entidad efectuará la evaluación respectiva. En nuestra apreciación, ello implica que para determinar si un desembolso califica o no como activo se realicen juicios o criterios basados en la evidencia y experiencia profesional, así como la evaluación del criterio de materialidad, que para efectos financieros se enmarcan en el objetivo de que la información financiera sea razonable y proporcione información útil a los usuarios de dicha información.

Sobre el particular se señala en el documento "Etapa 1 - Propiedades, Planta y Equipo" del material didáctico sobre las NIIF:

En gran medida, los informes financieros se basan en estimaciones, juicios profesionales y modelos, y no en descripciones exactas de la realidad (párrafo OB11 del Marco Conceptual). Para la entrega de información relevante sobre una entidad se requiere de estimaciones y juicios profesionales. Por ejemplo, se requieren muchas estimaciones para la medición del costo de un elemento de PPE. (Fundacion IFRS, 2014, pág. 20)

De igual manera, Manzano Albor expone sobre la realización de juicios: "Como es lógico, la norma no establece parámetros monetarios con vistas al reconocimiento de activos inmovilizados materiales. Por ello, se requiere la realización de juicios para aplicar los criterios de reconocimiento a las circunstancias específicas de la entidad" (Manzano Albor, 2007, p. 3).

Al respecto, corresponde tener en consideración el impacto, para fines tributarios, del tratamiento aplicable a los desembolsos posteriores, que consideran que, en el caso específico de los “costos posteriores”, se ha realizado una remisión expresa a las normas contables para 
definir si son parte del "costo computable" bajo una fórmula legal abierta y general sin aplicación de límites cuantitativos o cualitativos.

Sin duda, consideramos que, en la práctica, surgirán controversias entre el contribuyente y la Sunat respecto de la postura o tratamiento otorgado a determinada transacción que resulte compleja. En el capítulo III: Costos posteriores, desarrollamos supuestos específicos de desembolsos posteriores, que permitan apreciar su tratamiento contable y efecto tributario.

\section{b) Desembolsos que se reconocen como gasto}

Conforme con lo antes expuesto, aquellos desembolsos posteriores relacionados con la reparación y conservación del bien que mantienen el nivel de servicios del activo deben reconocerse como gasto. Ello, acorde con lo previsto en el párrafo 12 de la NIC 16, que los describe como "costos ${ }^{\mathbf{1 6}}$ derivados del mantenimiento diario del elemento" y que comprenden principalmente "los costos de mano de obra y los consumibles, que pueden incluir el costo de pequeños componentes”.

En la doctrina contable, a dichos desembolsos se les suele denominar bajo el término "reparación ordinaria" y "mantenimiento menor" a fin de limitar su alcance a aquellos rutinarios y planificados, que tienen por finalidad que los bienes vuelvan a funcionar (reparaciones) o continúen funcionando (mantenimiento) en forma adecuada, óptima y acorde al nivel de servicio requerido.

A título de resumen de lo abordado en el presente numeral, presentamos el esquema siguiente:

Figura 1.2.

\section{CONDICIONES PARA EL RECONOCIMIENTO EN EL RUBRO DE PROPIEDADES, PLANTA Y} EQUIPO

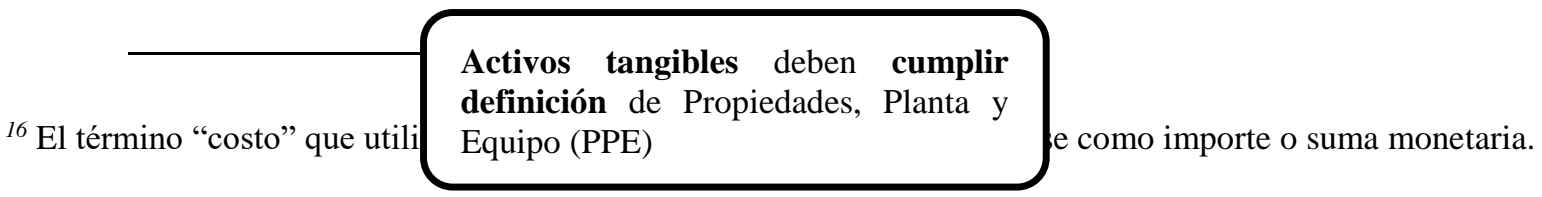




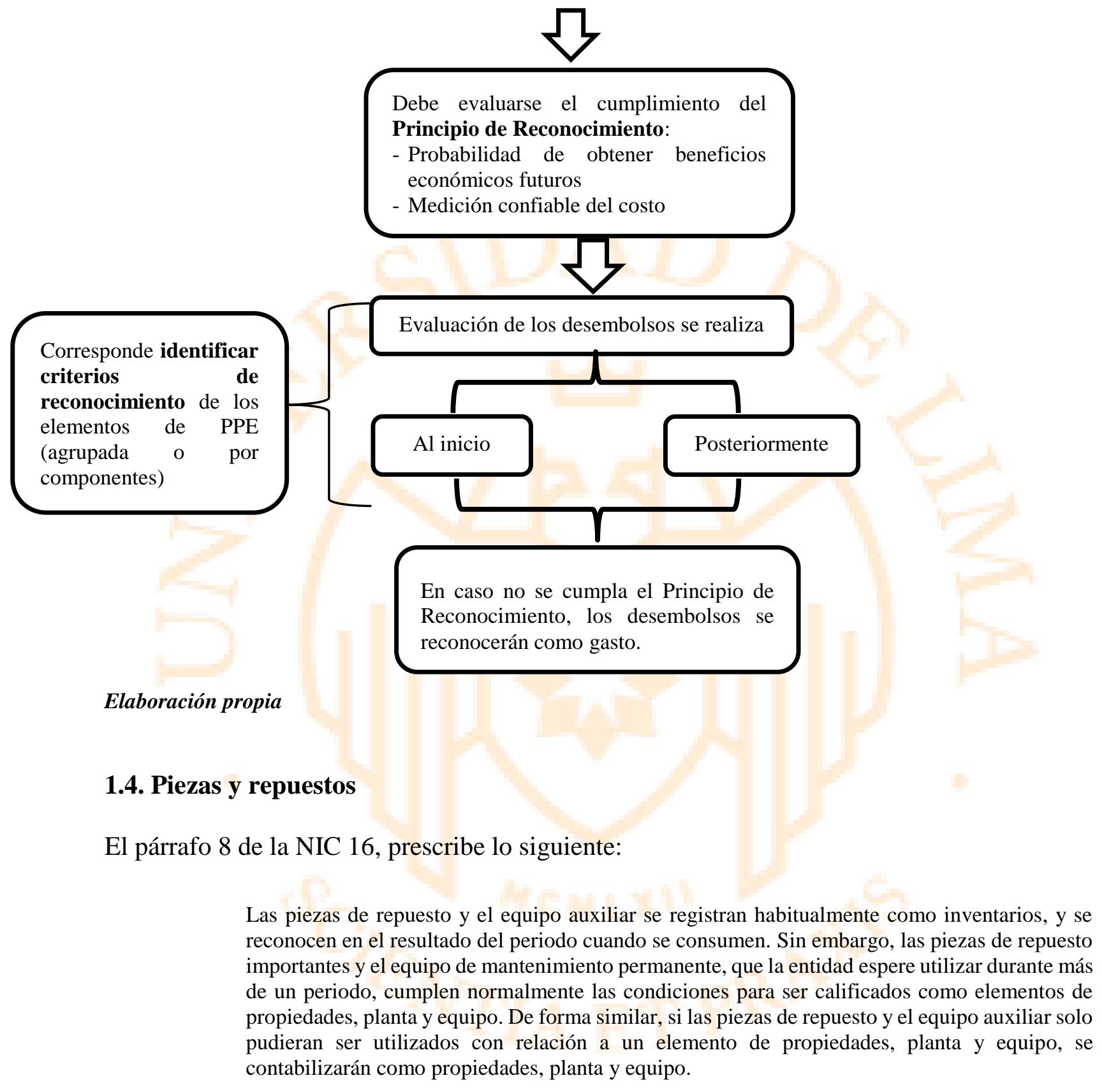

Se aprecia que, de acuerdo con lo dispuesto en la NIC 16, las piezas o repuestos según su naturaleza y características o uso, podrían reconocerse como un elemento de propiedad, planta y equipo. 
Así, las piezas de repuesto importantes que cumplen las condiciones de reconocimiento constituirían un costo posterior y que, según corresponda, se reconocerán como un componente del bien con el cual se vincula. El equipo de mantenimiento permanente, que también cumpla las condiciones de reconocimiento según su naturaleza, podría constituir un activo independiente o un componente del activo con el cual se vincula y, acorde a ello, calificaría como un costo posterior. Véase al respecto el capítulo II.

Las piezas de repuesto y equipo auxiliar, por su parte, que se utilizan con un solo bien calificarán como activo del rubro propiedad, Planta y Equipo, entendemos, en la medida que cumplan principio de reconocimiento, calificarían como costos posteriores.

Resulta importante observar que, en virtud del párrafo 55 de la NIC 16, la depreciación se inicia cuando los bienes se encuentran en la condición y ubicación necesaria para operar de acuerdo con la forma prevista por la gerencia. Por lo cual, en tanto las piezas de repuesto y equipo de mantenimiento o auxiliar que califican como propiedad, Planta y Equipo se encuentren en el almacén, no se inicia su depreciación. En tal supuesto, resulta recomendable evaluar, al cierre de cada ejercicio, si han sufrido desvalorización.

Para efectos tributarios, de acuerdo con el artículo 38 del TUO de la LIR, la depreciación se inicia cuando los bienes se destinan a la generación de rentas gravadas. 


\section{Capítulo II: RECONOCIMIENTO POR COMPONENTES}

En el presente capítulo, se desarrollan los requerimientos previstos en la NIC 16 y la doctrina contable respecto de la componentización y su clasificación al plantear el tratamiento tributario que correspondería otorgarle.

\subsection{Criterio de reconocimiento de las partidas de propiedad, planta y equipo}

El párrafo 9 de la NIC 16 señala que "Esta norma no establece la unidad de medición para propósitos de reconocimiento, por ejemplo, no dice en qué consiste una partida de propiedades, planta y equipo. Por ello, se requiere la realización de juicios para aplicar los criterios de reconocimiento a las circunstancias específicas de la entidad (...)”.

Bautista Mesa opina respecto de la unidad de cuenta o medición que:

La definición de la unidad de cuenta de los elementos de Propiedades, planta y equipo en ocasiones no coincide con el bien físico. (...) En ocasiones, hemos de distinguir períodos y/o ritmos diferentes en componentes separados de un mismo activo físico, e incluso una clasificación diferente dentro del propio estado de situación financiera. Este proceso se denomina contabilidad de componentes. La unidad de cuenta no es el bien físico cuando los componentes vayan a prestar servicios en periodos diferentes o cuando los componentes tengan un doble destino. (...) (Bautista Mesa, 2015, pág. 18)

Se aprecia, en función de ello, que cada entidad bajo la aplicación del juicio profesional a circunstancias que le son inherentes cumplirá los requerimientos de la NIC 16 y efectuará el reconocimiento de los activos conformantes de este rubro en forma individual, agrupada (tales como: moldes, herramientas y troqueles) o por componentes. De esta manera, la depreciación se realizará en función de los componentes identificados y de acuerdo con su vida útil.

En la obra Insights Into IFRS se expone respecto de la estimación del costo de los componentes:

3.2.240.20 En muchos casos, una entidad adquiere un activo por una determinada suma sin conocer el costo de los componentes individuales. En nuestro punto de vista, el costo de los componentes individuales debería ser estimados ya sea con referencia a los precios actuales en el mercado (si es posible), consultando al vendedor o contratista, o usando algún otro método razonable de aproximación-ej. valores relativos (KPMG, Insights into IFRS, 2019, pág. 472).

De acuerdo con especialistas en materia contable, el reconocimiento por componentes del rubro propiedad, planta y equipo -según la envergadura- puede involucrar costos 
relevantes para una compañía, además de resultar complejo e, inclusive, requeriría la contratación de expertos y realización de estudios técnicos para "estimar razonablemente" el valor de los componentes, además de la adecuación de los sistemas de control e identificación de los bienes.

\section{Figura 1.3.}

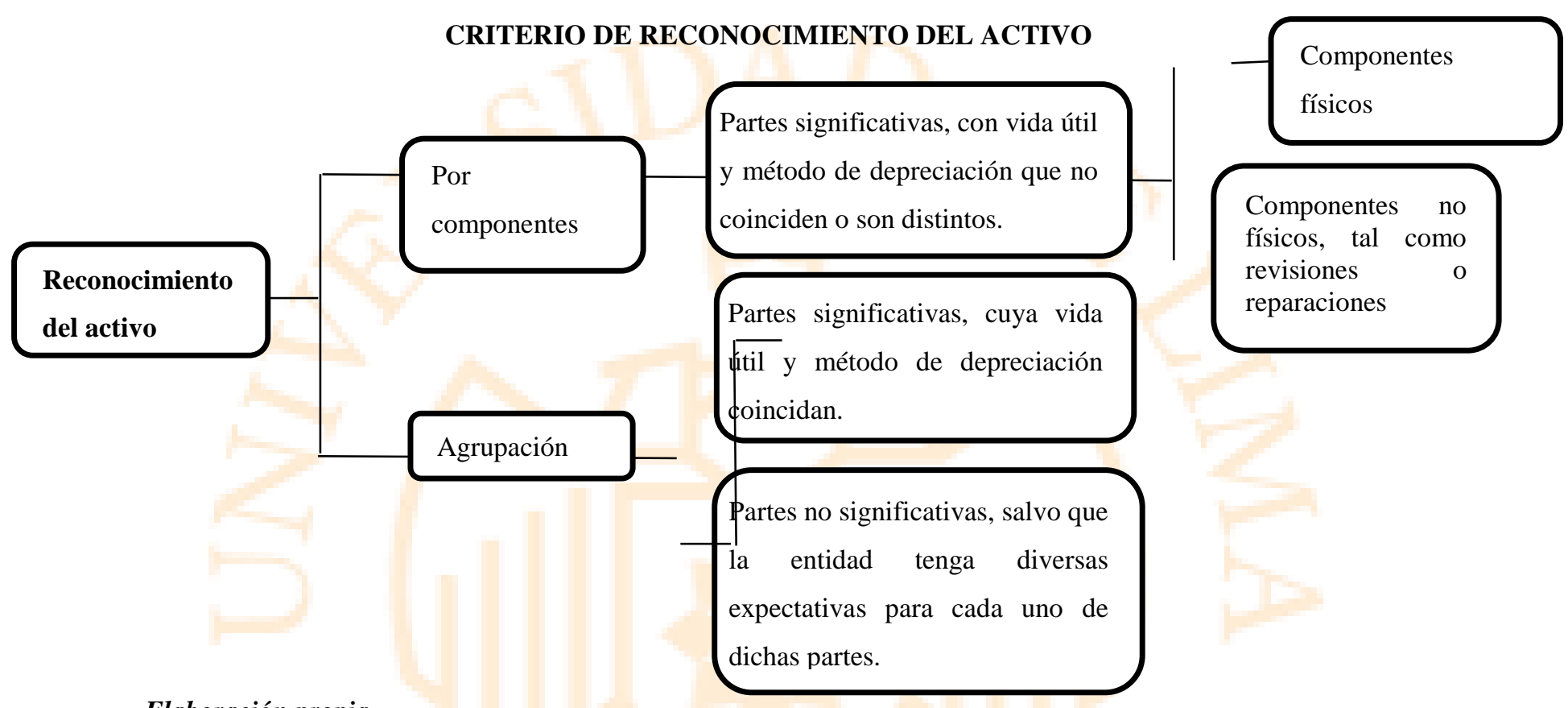

\section{2. ¿El reconocimiento por componentes implica que ya no se considere un único activo?}

El requerimiento de la NIC 16 de reconocer por componentes un activo tiene como objetivo la depreciación diferenciada de las partes de un bien que tengan un costo material o importante siempre que su vida útil y método de depreciación sean distintos de otras partes.

En la obra Las NIIF comentadas se señala que "la contabilización por componentes es obligatoria cuando resulta aplicable. Sin embargo, esto no significa que una entidad debe dividir sus activos en un numero infinito de componentes si el efecto en los estados financieros fuera inmaterial” (KPMG, Las NIIF comentadas, 2012, pág. 334).

Calzada Mesura indica, respecto de este criterio, que "la idea es "descomponer" el activo principal en sus componentes principales para depreciarlo de acuerdo con distintas 
vidas útiles, (...). Con esto, lo que se busca es ser más justos en la depreciación de los activos principales de la empresa" (Calzada Mezura, 2011, pág. 1).

En consideración al análisis previo y a efectos de dar respuesta a la pregunta planteada en el epígrafe, la componentización implica la asignación del costo del activo a sus partes significativas o al resto del elemento para efectos de depreciación, reemplazos o sustituciones; pero, bajo nuestra apreciación, ello no implica que se deje de presentar en los Estados Financieros como un único activo.

A mayor abundamiento, en la obra Las NIIF comentadas se concluye que:

Aunque los componentes individuales se contabilicen por separado, los estados financieros deben continuar revelando información sobre un único activo. Por ejemplo, una aerolínea generalmente revelará información de un avión como una clase de activo, en lugar de dar información separada respecto del fuselaje del avión, la parte hidráulica, los motores, los asientos, etc. (KPMG, Las NIIF comentadas, 2012)

\subsection{Depreciación por componentes}

En el párrafo 44 de la NIC 16 se prevé que "una entidad distribuirá el importe inicialmente reconocido con respecto de una partida de propiedades, planta y equipo entre sus partes significativas y depreciará de forma independiente cada una de estas partes." De igual modo, el párrafo 45 requiere que: "Una parte significativa de un elemento de propiedades, planta y equipo puede tener una vida útil y un método de depreciación que coincidan con la vida y el método utilizados para otra parte significativa del mismo elemento. En tal caso, ambas partes podrían agruparse para determinar el cargo por depreciación".

Respecto de cada componente identificado de una partida de propiedad, planta y equipo se calculará la depreciación. En el caso de un grupo de partes significativas que hayan sido agrupadas, se determinará la depreciación respecto del conjunto; en forma similar, se procederá con el resto del elemento que se haya agrupado por partes no significativas respecto del costo total del activo.

Procede señalar que si se produce el reemplazo de un componente, deberá darse de baja este con su correspondiente depreciación para reconocer el costo de la nueva pieza o 
componente, en función de su vida útil y método de depreciación. En virtud de ello, el reconocimiento por componentes cobra particular relevancia cuando se incurre en desembolsos posteriores. Este tópico se aborda con mayor detalle en el capítulo siguiente.

\subsection{El reconocimiento por componentes y su incidencia tributaria}

El reconocimiento por componentes incide directamente en el cálculo de la depreciación que se registra contablemente, en consecuencia tendrá también repercusión fiscal. Al respecto, se esgrimen dos posibles tratamientos por otorgar respecto de la determinación de la depreciación tributaria y que corresponderían a:

(i) Calcular la depreciación tributaria al bien en su conjunto, considerando la tasa máxima fijada.

(ii) Calcular la depreciación tributaria a cada uno de sus componentes identificados, considerando la tasa máxima fijada.

En nuestra apreciación, dado que el reconocimiento por componentes no ha sido propiamente contemplado en la legislación del impuesto a la renta, correspondería aplicar el primer criterio bajo el entendido que los porcentajes máximos tributarios se han fijado respecto de un único activo y que sería el adquirido o construido. Además, un argumento que abonaría en contra del segundo criterio sería que los valores de cada componente se determinan en función de estimaciones al amparo de las normas contables, no obstante constituye una técnica no admitida para fines tributarios.

En el presente apartado, hemos analizado los posibles tratamientos que podrían considerarse para fines tributarios con relación al reconocimiento inicial por componentes. Sin perjuicio de ello, en lo absoluto se pretende dar por agotado el tema, sino contribuir con la fijación de posturas que coadyuven a perfeccionar la regulación fiscal y minimizar contingencias tributarias.

A mayor abundamiento, surgen también cuestionamientos respecto del tratamiento tributario a considerar cuando se produce la sustitución de componentes y por ende procede 
la baja de aquellos que están siendo reemplazados. Sobre el particular, véase el numeral 1.2.6 del capítulo siguiente.

Finalmente, a título enunciativo, debe observarse que, para la deducibilidad de la depreciación, deben observarse los requisitos y condiciones reguladas en la LIR (Artículos 38, 39 y 41) y su reglamento (Artículo 22). Así, entre otros, debe acreditarse el uso del bien en las actividades de la empresa, la base de cálculo debe corresponder al costo de adquisición o costo construcción, la depreciación se debe encontrar registrada contablemente y no debe exceder el porcentaje máximo establecido. 


\section{Capítulo III: COSTOS POSTERIORES}

En este capítulo, se exponen supuestos específicos de desembolsos que se incurren con posterioridad al reconocimiento inicial del activo y analiza el tratamiento contable que le resultaría aplicable. En correlato con ello, se desarrolla respecto de la sustitución de componentes y el procedimiento para estimar el valor del componente sustituido considerando los requerimientos previstos en la NIC 16.

En el análisis, se plantean las incongruencias o diferencias que surgirían respecto del tratamiento tributario aplicable.

\subsection{Costo vs. gasto}

La NIC 16 en su párrafo 10, al señalar el cumplimiento del principio de reconocimiento general para los desembolsos posteriores, expresa: "Estos costos comprenden (...) los costos incurridos posteriormente para añadir, sustituir parte de o mantener el elemento correspondiente."

Se observa en función de ello, que los desembolsos posteriores corresponderían a:

\section{Adición}

Sustitución

$>$ Reparación, mantenimiento (conservación)

Si bien el tratamiento a otorgar a los desembolsos posteriores se encuentra previsto en la NIC 16, no obstante, en la práctica frente a diferentes transacciones o supuestos producidos, efectuar una adecuada conceptualización e identificación del cumplimiento o no del principio de reconocimiento resulta en no pocas ocasiones compleja, lo que ameritará una evaluación y análisis muy cuidadoso de los diferentes profesionales involucrados.

Tal como expresan diversos autores, cuando se efectúan las reparaciones y estas ameritan ser capitalizadas, se deberán tratar como adición, mejora o reemplazo según sea el más apropiado. Por ello, en la doctrina contable se utilizan los términos "reparación ordinaria" (gasto) y "reparación mayor" (activo), así como "mantenimiento menor" (gasto) y “mantenimiento mayor" (activo) para diferenciar el tratamiento contable a otorgarle. 
Valiente señala que:

Para discernir si un desembolso es o no capitalizable o activable (mayor valor del activo) hay que ir al fondo del problema y recordar lo que es un activo y un gasto de operación. Un activo es un coste que tiene efectos positivos en el futuro (...). Por contra, un gasto de operación (que no se incluye en el activo) es aquel coste que solo tiene utilidad en un período y, por tanto, se regulariza en su totalidad, con resultados. (Teoría de la Contabilidad Financiera, 2004, pág. 102)

A nivel tributario, igualmente surgen diferentes criterios y/o posturas para determinar si un desembolso califica como costo o gasto, lo que produce controversias entre los contribuyentes y la Sunat. Citamos, a título ilustrativo, un criterio del Tribunal Fiscal que permite apreciar los argumentos esgrimidos para identificar si los desembolsos son costo o gasto ${ }^{17}$ así como las condiciones o acreditación requerida para definir su tratamiento:

Lo resuelto en la RTF 07969-8-2014 de 30-6-14 es ilustrativo de la variedad de criterios que aplica el Tribunal Fiscal para pronunciarse sobre los reparos a la deducción de los gastos considerados como inversión en activos por la SUNAT:

- Adquisición de portones, puerta metálica y puerta de aluminio: “Carecen aisladamente de utilidad para las empresas, no calificando por sí mismos como activos fijos, por lo que corresponde analizarlos en conjunto con el bien principal (inmueble) para de esta manera determinar si constituyen "gastos" al constituir parte del mantenimiento que tiene como propósito que el activo principal funcione correctamente y en toda su capacidad o un "activo" representado en una mejora de carácter permanente que supone que el inmueble tenga un rendimiento mayor al que se espera del mismo." La Administración no puede limitarse a calificar su compra como activos sin acreditar debidamente ello.

- Arreglo de ambientes del mostrador para ampliar sus dimensiones: Por la naturaleza del desembolso constituye una mejora de carácter permanente ${ }^{18}$.

- Instalación de sistemas operativos (cómputo): La Administración debe identificar claramente el activo respecto del cual se prestó ese servicio para sustentar que el importe desembolsado debe ser activado. (RTF, 2014)

En la RTF citada, dado que el ejercicio fiscalizado corresponde a uno anterior al ejercicio 2013, el Tribunal Fiscal analiza y define el tratamiento por aplicar para fines tributarios bajo la consideración si califica o no como una "mejora de carácter permanente" acorde con lo previsto en los Artículos $20^{\circ}$ y $41^{\circ}$ de la LIR vigente hasta el ejercicio 2012. No

17 Sumilla desarrollada en el Apéndice de Jurisprudencia en línea de Editorial Economía y Finanzas: https://www.eef.com.pe/verapendice.php?id=UXrK8B9wbRBdQOEfh37UCw\&keyword=mantenimiento, visitado el 30 de agosto 2019.

${ }^{18}$ Dado que el ejercicio fiscalizado corresponde a uno anterior al ejercicio 2013, se usa el término "mejora de carácter permanente" 
obstante, a efectos de evaluar si se está frente a una mejora, considera similares criterios y parámetros a los que se fijaban en la NIC 16 (modificada en 1998) y cuya vigencia en Perú fue hasta el ejercicio 2005.

Como hemos señalado, en el subnumeral 1.3.3.1 del capítulo I, la actual NIC 16 determina en forma general el cumplimiento del principio de reconocimiento para identificar si un desembolso posterior califica como activo sin fijar parámetros o condiciones específicas. Además, se requiere la aplicación de la experiencia y juicio profesional para definir si amerita reconocerse como activo o, por el contrario, procedería su afectación a resultados, ello según la naturaleza de cada caso concreto.

Inclusive para efectos financieros a fin de que se cumpla con el requerimiento que los estados financieros presenten razonablemente los efectos de las transacciones, corresponde aplicar -entre otros- las características fundamentales de "relevancia" y "representación fiel" siendo necesario para ello el criterio de materialidad o importancia relativa.

Kieso y Weygandt, expresan que "muchas empresas han adoptado la regla de que los gastos menores (...), se cargaran siempre a gastos. Aunque conceptualmente este tratamiento puede parecer incorrecto, la agilización lo exige” (Kieso \& Weygandt, 1999, pág. 573).

Apreciamos que, a nivel fiscal, la aplicación de dichos juicios, criterios y características no resultarían aplicables, ya que responden a aspectos subjetivos y estimaciones, supuestos no admitidos por la legislación del impuesto a la renta en virtud del literal f) Artículo $44^{\circ}$ del TUO LIR. A título de recordatorio, la LIR solo permite expresamente que los activos fijos cuyo costo (del bien en su conjunto) no supere $1 / 4$ UIT se reconozcan como gasto. 
Sobre el particular, en la exposición de motivos del decreto legislativo $\mathrm{N}^{\circ} 1425^{19}$ se señala que:

(...) no resulta razonable que la determinación del impuesto a la renta y por ende el monto que se recaude por dicho impuesto se encuentre sujeto a una estimación de carácter subjetivo, respecto de si efectivamente el sujeto va a recibir o no ingresos. Cabe mencionar que por esta misma razón no se admite la deducción de provisiones genéricas en la determinación de las rentas neta de tercera categoría. (2018)

\subsection{Tipos de costos posteriores}

La NIC 16 regula el "principio de reconocimiento" como condición para reconocer cualquier desembolso posterior como parte del rubro de propiedad, planta y equipo (activo). En tal sentido, no efectúa una descripción de los tipos de desembolsos que calificarían como costos posteriores.

Sin perjuicio de ello, la doctrina contable especializada menciona algunos tipos de costos posteriores. Kieso y Weygandt, señalan que "si se presenta una reparación mayor (...) el costo se manejará como adición, mejora o reemplazo" (1999, pág. 575).

Apreciamos importante determinar respecto de los desembolsos posteriores a qué tipo de costo corresponde, ya que ello coadyuva a efectuar una debida identificación y tratamiento, además de la incidencia o efecto que pueden tener respecto de la depreciación como se analiza en el numeral 1.5 del presente capítulo.

\subsubsection{Adición, ampliación o expansión}

Este tipo de desembolso posterior se relaciona con la adición o ampliación física de un activo. Respecto de este concepto, el análisis a nivel contable, se centra en los aspectos siguientes:

${ }^{19}$ Dispositivo legal que modifica el Artículo $57^{\circ}$ del TUO de la Ley del Impuesto a la Renta incorporando las reglas para la aplicación del Devengo. 
(i) Verificar si cumple el principio de reconocimiento para que sea reconocido como activo.

(ii) Identificado que, sí califica como un activo, determinar si procede que sea reconocido como un componente del activo ya existente (costo posterior) o por el contrario, merecería reconocerlo como un activo distinto e independiente.

Por ejemplo, en una edificación dos pisos, se decide construir nuevas oficinas y para ello se construyen 2 pisos adicionales. Además, adquiere e instala un ascensor y un sistema de aire acondicionado en el edificio.

Sobre dicho planteamiento, partimos de la premisa que tanto las nuevas oficinas como el ascensor cumplen el principio de reconocimiento y, por tanto, califican como activo. En función de ello, el análisis siguiente es determinar si constituyen componentes del activo o por el contrario activos distintos:

(i) Nuevas oficinas: No advertiría mayor dificultad y constituiría un componente del activo principal: Edificio, es decir sería un costo posterior.

(ii) Instalación de nuevo ascensor y sistema de aire acondicionado: Sobre este rubro se presentan dudas, entre los contribuyentes, si debe considerarse como un componente del edificio (costo posterior) o por el contrario debería considerarse un activo distinto.

La Dirección Nacional de Contabilidad Pública, en su sección preguntas frecuentes, Propiedad, planta y equipo ${ }^{20}$, plantea la pregunta y respuesta siguiente:

01. ¿La compra de un ascensor, se considera como bien de capital, y debe ser contabilizado en la cuenta $1503^{21}$ Vehículos, Maquinarias y Otros?

Un ascensor es un bien que por sí mismo, no cumple una función o presta un servicio, requiere estar instalado en una edificación para que su función tenga una utilidad identificable, por lo que el ascensor es considerado como parte del edificio, debiendo registrarse como Edificios y Estructuras (15.01), en la cuenta divisionaria que corresponda, de acuerdo con la edificación que se ha construido y en la cual brinda servicios. (Ministerio de Economia y Finanzas, s.f.)

En el Informe N $\mathrm{N}^{\mathrm{0}}$ 124-2010-SUNAT/2B0000, SUNAT esgrime las conclusiones siguientes:

\footnotetext{
${ }^{20}$ https://www.mef.gob.pe/es/preguntas-frecuentes-sp-10033/propiedad-planta-y-equipo, fecha de acceso 12 de enero de 2020.

${ }^{21}$ Divisionaria del Plan Contable Gubernamental.
} 
1. Para fines del Impuesto a la Renta, dentro de la expresión "edificaciones y construcciones" deben entenderse comprendidas las edificaciones propiamente dichas y toda construcción, obra de arquitectura o ingeniería que tienen como característica su fijeza y permanencia, ésta última asociada a una vida útil relativamente extensa, similar a la que corresponde a un edificio (...).

2. Formarán parte de las edificaciones y construcciones (...) los aditamentos de carácter permanente que tengan una vida útil relativamente larga como la obra. (SUNAT, Informe Nro. 124-2010-SUNAT/2B0000, 2010)

Similar criterio se señala en la RTF 919-1-2019:

(...) las instalaciones fijas y permanentes son todos los bienes que se encuentran adheridos físicamente a la edificación y no pueden ser separados de este sin destruirlo, deteriorarlo o alterar su valor, y califican como tales, como se indica el Reglamento Nacional de Tasaciones, las instalaciones de bombeo, instalaciones exteriores eléctrica y sanitarias, ascensores, instalaciones contra incendios e instalaciones de aire acondicionado (...) $(\mathrm{RTF}, 2019)$

En función de lo expuesto, se aprecia que la instalación de un ascensor y un sistema de aire acondicionado calificarían como costos posteriores y por tanto partes componentes de un edificio. Por tanto, no sería adecuado tratarlos como activos distintos o independientes.

\subsubsection{Mejoras}

A nivel tributario, se utilizó, hasta el ejercicio 2012, el término "Mejoras permanentes" a efectos de referirse a los desembolsos posteriores que debían formar parte del costo del activo $^{22}$. A partir del ejercicio 2013 se sustituye dicho término por el de "costos posteriores" a fin de equiparse con lo previsto en la NIC 16.

Por ello, se puede apreciar que los criterios del Tribunal Fiscal, que resuelven reparos relacionados con desembolsos posteriores hasta el ejercicio 2012, analizan si estos calificaban o no como "mejoras".

Sin perjuicio de lo expuesto, cabe indicar que, de acuerdo con la doctrina contable, el término "mejora" corresponde a un tipo de costo posterior y que es definido como un incremento cualitativo en la capacidad de producción o rendimiento del activo, respecto de la que tenía originalmente. Así, en el Boletín Técnico 33 del Colegio de Contadores de Chile se expresa que "(...) se denominan costos de adiciones y mejoras aquellos en que se incurre con

\footnotetext{
${ }^{22}$ Véase página 16 del presente trabajo de investigación.
} 
el objeto específico de extender significativamente la vida útil, o incrementar significativamente la capacidad productiva o eficiencia original del bien" (Colegio de Contadores de Chile, pág. 2).

En el Boletín Oficial del Estado (BOE) $\mathrm{N}^{\circ} 58$, se precisa que "2. Se entiende por «mejora» el conjunto de actividades mediante las que se produce una alteración en un elemento del inmovilizado, aumentando su anterior eficiencia productiva". (Instituto de Contabilidad y Auditoria de Cuentas, 2013, pág. 18446).

En la RTF 3718-1-2006, se expresa la diferenciación entre “adición” y “mejora”:

(...) de acuerdo a los autores antes citados ${ }^{23}$ la diferencia esencial entre una adición y una mejora está en que la primera lleva consigo un aumento de cantidad, mientras que en la segunda existe una sustitución que aumenta solo la calidad;(...) (RTF, 2006)

\subsubsection{Reconstrucción}

Javier Romero López, respecto de este concepto, cita lo señalado en el Boletín C-6:

Algunos activos pueden sufrir modificaciones tan completas que más que adaptaciones o reparaciones, estos cambios representan verdaderas reconstrucciones. Esta situación puede encontrarse principalmente en el caso de edificios y en cierto tipo de máquinas. Es indudable que las reconstrucciones aumentan el valor de activo fijo y por lo tanto son partidas capitalizables (...). (Romero, 1996, pág. 36)

Procede indicar que si la reconstrucción conlleva la eliminación parcial o total de del activo reconstruido, correspondería efectuar su baja en cuentas en virtud del literal b) del párrafo 67 de la NIC 16. Ello bajo el entendido que ya no generará beneficios económicos futuros.

A través del Informe No 026-2010/SUNAT/2B0000, SUNAT, concluye respecto del tratamiento por otorgar cuando se produce la demolición de una edificación:

En relación con la baja de inmuebles, para fines del Impuesto a la Renta, el valor en libros pendiente de depreciación correspondiente a la edificación demolida debe deducirse para la determinación de la renta neta en el ejercicio en que se concluya la demolición. (SUNAT, 2010)

Similar criterio se ha esbozado a través de la Carta No 084-2011-SUNAT/ 200000 y que referimos a continuación:

\footnotetext{
${ }^{23}$ En la RTF citada se cita a los autores Kieso y Weygandt así como H.A. Finney y H.E. Miller
} 
Al respecto, cabe indicar que en el mencionado informe (corresponde al Informe No 026-2010SUNAT/2B0000) se ha concluido que, para fines del Impuesto a la Renta, el valor en libros pendiente de depreciación correspondiente a la edificación demolida debe deducirse para la determinación de la renta neta en el ejercicio en que se concluya la demolición.

Dicha conclusión se sustenta en el análisis contable efectuado en el citado documento, según el cual, en aplicación del literal b) del párrafo 67 de la NIC 16, corresponde dar de baja en libros el valor pendiente de depreciación de la edificación demolida, toda vez que esta no proporcionara beneficios económicos futuros.

Asimismo, conforme a dicho análisis, la pérdida o ganancia derivada de la baja deberá ser incluida en el resultado del periodo cuando la partida sea dada de baja, tal como se desprende del párrafo 68 de la citada NIC. (2011)

\subsubsection{Reemplazos (o sustituciones) importantes}

El párrafo 13 de la NIC 16 señala que:

Ciertos componentes de algunos elementos de propiedades, planta y equipo pueden necesitar ser reemplazados a intervalos regulares. (...) Ciertos elementos de propiedades, planta y equipo pueden ser adquiridos para hacer una sustitución recurrente menos frecuente, (...) De acuerdo con el criterio de reconocimiento del párrafo 7 , la entidad reconocerá, dentro del importe en libros de un elemento de propiedades, planta y equipo, el costo de la sustitución de parte de dicho elemento cuando se incurra en ese costo, siempre que se cumpla el criterio de reconocimiento. El importe en libros de esas partes que se sustituyen se dará de baja en cuentas (...)

Obsérvese que, en este supuesto, la determinación de su tratamiento como costo se supedita al cumplimiento del principio de reconocimiento. Acorde a lo expresado por diferentes autores, el término reemplazo comprende aquellos desembolsos por los cuales se restauran la capacidad inicial o características iniciales de funcionamiento de un bien.

En la doctrina, se le denomina también bajo el término de "Renovación". Bautista Mesa, indica que "las renovaciones de elementos clasificados como propiedades, planta y equipo suponen la realización de las actuaciones necesarias para la restauración del activo o de un componente suyo” (Bautista Mesa, 2015, pág. 105).

Ilustramos, a continuación, este supuesto con un criterio vertido por el Tribunal Fiscal (Editorial Economia y Finanzas, s.f.) ${ }^{24}$ :

24 Sumilla desarrollada en el Apéndice de Jurisprudencia en línea de Editorial Economía y Finanzas: https://www.eef.com.pe/verapendice.php?id=n\$cW61rFA:7Iq\$0MqmT1tA\&keyword=9478, visitado el 12 de enero 2020. 
En el caso de la RTF 9478-1-2013 de 7-6-13 se discutió si lo desembolsado por una empresa generadora de energía eléctrica a favor de un tercero por el servicio de reparación integral de una turbina que había sufrido graves daños durante su funcionamiento y la habían inutilizado, constituían mejoras o gastos de reparación.

Los servicios contratados comprendían la reparación integral del estátor del generador, que incluía el suministro de bobinas nuevas, repuestos, desmontaje e instalación, así como sus pruebas y recepción.

El Tribunal Fiscal hizo referencia a los párrafos 13 y 28 de la NIC 16, según los cuales los desembolsos incurridos al reemplazar o renovar un activo se contabilizan como activos separados y señaló que dado que los servicios del tercero habían comprendido, entre otros, "la entrega de un nuevo estator, componente fundamental del generador que a su vez es el elemento fundamental de la turbina, lo que permitió poner en estado de operatividad la planta, los servicios prestados ampliaron el rendimiento de la turbina más allá del estándar originalmente proyectado, y al tener mayor vida útil debieron ser activados ...”.

Nota: De acuerdo con esta resolución, la reparación integral de un equipo que ha sufrido una avería que lo inutiliza totalmente, la cual incluye la reparación de uno o más componentes fundamentales y el suministro de nuevos componentes, constituye una mejora ${ }^{25}$ y no una reparación.

El tratamiento por otorgar a las partes que se sustituyen se desarrolla en el numeral 1.4 del presente capítulo.

\subsubsection{Controversias tributarias}

La complejidad para identificar el tratamiento contable respecto de los desembolsos posteriores genera también controversias a nivel tributario y que puede originar contingencias tributarias. A continuación, citamos dos resoluciones presentando el tratamiento otorgado por el contribuyente, el reparo de Sunat y los argumentos del Tribunal Fiscal ${ }^{26}$.

\begin{tabular}{|c|c|c|c|c|}
\hline $\begin{array}{c}\text { Desembolso } \\
\text { incurrido }\end{array}$ & $\begin{array}{c}\text { Tratamiento } \\
\text { brindado por } \\
\text { el } \\
\text { contribuyente }\end{array}$ & $\begin{array}{c}\text { Criterio de la } \\
\text { SUNAT }\end{array}$ & $\begin{array}{c}\text { Criterio del Tribunal } \\
\text { Fiscal }\end{array}$ & Comentarios \\
& & & \\
\hline
\end{tabular}

\footnotetext{
${ }^{25}$ Entiéndase de acuerdo a la legislación vigente, referido a Costo Posterior.

${ }^{26}$ Hemos seleccionado las resoluciones dado que corresponden al ejercicio 2019, ello sin dejar de mencionar que existe abundante jurisprudencia sobre este tópico, lo que trasciende respecto de las dificultades conceptuales y prácticas que se presentan para determinar su tratamiento adecuado.
} 


\begin{tabular}{|c|c|c|c|c|}
\hline $\begin{array}{l}\text { Remodelación } \\
\text { y } \\
\text { reconstrucción } \\
\text { de local } \\
\text { RTF 3925-4- } \\
2019\end{array}$ & Gasto & Costo & $\begin{array}{l}\text { Confirma el reparo } \\
\text { Sustento: } \\
\text { El contribuyente no } \\
\text { acredita } \\
\text { documentariamente el } \\
\text { motivo por el cual debía ser } \\
\text { considerado como gasto, ni } \\
\text { desvirtúa el reparo de } \\
\text { SUNAT. }\end{array}$ & $\begin{array}{l}\text { Si bien los conceptos de suyo } \\
\text { implican que dichos desembolsos } \\
\text { se deberían reconocer como costo, } \\
\text { debe tenerse presente que para ello } \\
\text { se debe cumplir el Principio de } \\
\text { Reconocimiento enunciado en la } \\
\text { NIC } 16 \text {. } \\
\text { Por nuestra parte compartimos el } \\
\text { criterio del Tribunal Fiscal, debido } \\
\text { a la falta de sustento y acreditación } \\
\text { por parte del contribuyente. }\end{array}$ \\
\hline $\begin{array}{l}\text { Letreros en } \\
\text { acero } \\
\text { inoxidable y } \\
\text { pantallas en } \\
\text { acrílico } \\
\text { RTF 3925-4- } \\
2019\end{array}$ & Gasto & Costo & $\begin{array}{l}\text { Confirma el reparo } \\
\text { Sustento: } \\
\text {-Cumplen con la definición } \\
\text { de la NIC } 16 \text { y se } \\
\text { enmarcan, por tanto, en la } \\
\text { regulación del literal e) } \\
\text { artículo } 44 \text { de la LIR. } \\
\text {-El contribuyente no ha } \\
\text { sustentado } \\
\text { documentariamente, que } \\
\text { dichas erogaciones debían } \\
\text { ser deducidas por la vía } \\
\text { del gasto debido al uso y } \\
\text { condiciones del bien. }\end{array}$ & $\begin{array}{l}\text { El Tribunal Fiscal, pone especial } \\
\text { énfasis en que fueron empleados } \\
\text { en el desarrollo de la actividad de } \\
\text { la recurrente por un período que se } \\
\text { esperaría supere más de un } \\
\text { período. } \\
\text { Es decir, se sustenta en el criterio } \\
\text { de "permanencia" del activo, } \\
\text { según la definición del párrafo } 6 \text { de } \\
\text { la NIC } 16 \text {. } \\
\text { Compartimos el criterio vertido } \\
\text { por el Tribunal Fiscal. }\end{array}$ \\
\hline $\begin{array}{l}\text { Blindaje del } \\
\text { vehículo } \\
\text { RTF 05020-1- } \\
2019\end{array}$ & $\begin{array}{l}\text { Gasto } \\
\text { Sustento: El } \\
\text { blindaje } \\
\text { automotriz } \\
\text { disminuye la } \\
\text { vida útil del } \\
\text { equipo al } \\
\text { generarle un } \\
\text { mayor peso, } \\
\text { por lo que } \\
\text { disminuye el }\end{array}$ & $\begin{array}{l}\text { Costo } \\
\text { Sustento: El } \\
\text { blindaje genera } \\
\text { beneficios a la } \\
\text { empresa, toda } \\
\text { vez que le } \\
\text { añade utilidad } \\
\text { adicional al } \\
\text { vehículo, esto } \\
\text { es brindar } \\
\text { seguridad a los } \\
\text { ocupantes, con }\end{array}$ & $\begin{array}{l}\text { Levanta el reparo } \\
\text { Sustento: } \\
\text { - SUNAT no analizo si el } \\
\text { desembolso aumentó la } \\
\text { vida útil o si, por el } \\
\text { contrario, aquellos fueron } \\
\text { utilizados con el fin de } \\
\text { repararlos o mantenerlos. } \\
\text { - Si SUNAT de su } \\
\text { evaluación establece que } \\
\text { dichos gastos no tienen } \\
\text { dicha naturaleza, } \\
\text { corresponde acreditar su } \\
\text { afirmación, lo que en el } \\
\text { caso no se encuentra } \\
\text { debidamente sustentado. }\end{array}$ & $\begin{array}{l}\text { El Tribunal Fiscal, expresa que: } \\
\text { “(...) de acuerdo con las normas } \\
\text { contables y criterios expuestos, es } \\
\text { posible concluir que los } \\
\text { desembolsos efectuados forman } \\
\text { parte de recomendaciones de } \\
\text { seguridad adoptados de manera } \\
\text { general lo que no necesariamente } \\
\text { genera beneficios económicos } \\
\text { futuros en exceso del activo (...)” } \\
\text { Lo señalado por el Tribunal Fiscal } \\
\text { se sustenta en el párrafo } 11 \text { de la }\end{array}$ \\
\hline
\end{tabular}




\begin{tabular}{|c|c|c|c|c|}
\hline & $\begin{array}{l}\text { rendimiento } \\
\text { estándar. }\end{array}$ & $\begin{array}{l}\text { lo cual la } \\
\text { utilidad y el } \\
\text { beneficio se ve } \\
\text { aumentada. }\end{array}$ & $\begin{array}{l}\text { - No se demuestra la } \\
\text { obtención de beneficios } \\
\text { económicos futuros del } \\
\text { activo, en exceso de los } \\
\text { que se obtendrían sino se } \\
\text { hubiera realizado los } \\
\text { desembolsos materia de } \\
\text { observación. }\end{array}$ & $\begin{array}{l}\text { NIC 16, en virtud del cual este tipo } \\
\text { de desembolsos incurridos por } \\
\text { razones de seguridad que no } \\
\text { incrementa los beneficios } \\
\text { económicos del activo existente, } \\
\text { cumplen las condiciones de } \\
\text { reconocimiento solo en la medida } \\
\text { que permitan a la entidad obtener } \\
\text { beneficios económicos adicionales } \\
\text { del resto de sus activos, respecto } \\
\text { de los que hubiera obtenido si no } \\
\text { los hubiera adquirido. } \\
\text { Apreciamos relevante el criterio } \\
\text { del Tribunal Fiscal, respecto de } \\
\text { que se debe encontrar debidamente } \\
\text { sustentado y acreditado, que el } \\
\text { desembolso incurrido, genera la } \\
\text { obtención de beneficios } \\
\text { económicos adicionales para el } \\
\text { resto de sus activos. Ello podría, } \\
\text { entre otros, efectuarse a través de } \\
\text { un Informe Técnico. }\end{array}$ \\
\hline
\end{tabular}

Elaboración propia ${ }^{27}$

\subsection{Inspecciones generales}

\section{El párrafo 14 de la NIC 16 regula que}

Una condición para que algunos elementos de propiedades, planta y equipo continúen operando, (por ejemplo, una aeronave) puede ser la realización periódica de inspecciones generales por defectos, independientemente de que las partes del elemento sean sustituidas o no.

Cuando se realice una inspección general, su costo se reconocerá en el importe en libros del elemento de propiedades, planta y equipo como una sustitución, si se satisfacen las condiciones para su reconocimiento. Al mismo tiempo, se dará de baja cualquier importe en libros del costo de una

27 Cuadro publicado como parte del artículo: Desembolsos vinculados con Activo Fijo, Costo vs. Gasto, publicado en la revista "Contadores y Empresas”, correspondiente a la segunda quincena de noviembre 2019, página A-9. 
inspección previa, que permanezca en la citada partida y sea distinto de los componentes físicos no sustituidos. Esto sucederá con independencia de que el costo de la inspección previa fuera identificado contablemente dentro de la transacción mediante la cual se adquirió o construyo dicha partida. Si fuera necesario, puede utilizarse el costo estimado de una inspección similar futura como indicador de cuál fue el costo del componente de inspección existente cuando la partida fue adquirida o construida.

En virtud de dicho requerimiento, si el activo o activos de este rubro se van a someter a inspecciones periódicas en el reconocimiento inicial del activo, deberá identificarse como un componente separado el costo estimado para su realización y, en atención a ello, se depreciará en función del tiempo, en el cual se proyecta realizar la próxima inspección o de ocurrir la inspección antes de lo programado el saldo por depreciar afectará a resultados.

En correlato con lo expuesto en el párrafo anterior, se deberá dar de baja el costo de una inspección previa, inclusive, cuando no se hubiera identificado por separado en la oportunidad de la adquisición o construcción del bien. Dicho procedimiento se desarrolla en el numeral 1.4 siguiente.

En la doctrina contable, se le suele denominar "mantenimiento mayor programado" o "gran reparación" y además se le considera como un componente "no físico". En la obra Las NIIF comentadas se precisa que “(...) La contabilización por componentes de los costes de revisiones o reparaciones está pensada solo para desembolsos muy importantes que ocurren a intervalos regulares a lo largo de la vida del activo. (...)" (KPMG, Las NIIF comentadas, 2012, pág. 336).

Ilustramos el tratamiento contable de las inspecciones generales requerido por la NIC 16 con un ejemplo desarrollado en la obra Insights Into IFRS:

Ejemplo 15A-Coste de "Overhaul"- Valor contable del componente

3.2.250.30 La compañía P dirige un comercio marítimo y acaba de adquirir un nuevo barco por 400. La vida útil del barco es 15 años, pero este podría tener su dique seco cada 3 años y una revisión importante será llevada a cabo. En la fecha de adquisición, los costes del dique seco para barcos similares que tienen 3 años de antigüedad son aproximadamente 80 .

3.2.250.35 Entonces, el coste del componente del dique seco para propósitos contables es 80 y esta cantidad se depreciaría a lo largo de los 3 años hasta el siguiente dique seco. El valor contable restante, el cual podría necesitar ser separado en otros componentes, es 320. Cualquier componente adicional sería depreciado sobre su propia vida útil estimada. (KPMG, 2019, pág. 472) 
En la RTF 4788-2-2018 (22.6.2018), se determina que "los desembolsos por servicios de overhaul y exchange de piezas y naves arrendadas que se encontraban contabilizadas como mejoras en equipos alquilados, califican como activo" (RTF, 2018).

\subsection{Tratamiento de los componentes de un activo que son sustituidos}

\subsubsection{Tratamiento contable}

El párrafo 67 de la NIC 16 señala que "el importe en libros de un elemento de propiedades, planta y equipo se dará de baja en cuentas: (...) (b) cuando no se espere obtener beneficios económicos futuros por su uso o disposición".

En virtud del párrafo 68 de la NIC 16, la pérdida o ganancia que surge por la baja del elemento de propiedades, planta y equipo se incluirá en el resultado del período cuando esta se produzca.

En el caso específico de la sustitución de los componentes de un activo, el párrafo 70 de la NIC 16 requiere que se brinde el tratamiento siguiente:

$\mathrm{Si}$, de acuerdo con el principio de reconocimiento del párrafo 7 , la entidad reconociera dentro del importe en libros de un elemento de propiedades, planta y equipo el costo derivado de la sustitución de una parte del elemento, entonces dará de baja el importe en libros de la parte sustituida, con independencia de si esta parte se hubiera amortizado de forma separada. Si no fuera practicable para la entidad determinar el importe en libros del elemento sustituido, podrá utilizar el costo de la sustitución como indicativo de cuál era el costo del elemento sustituido en el momento en el que fue adquirido o construido.

Por tanto, en el caso de que el producto del reconocimiento de un costo posterior produzca la sustitución de un componente del activo principal, la parte sustituida debe darse de baja y afecta al resultado del ejercicio. Obsérvese que, en este caso, la NIC 16 es mandatoria respecto del cumplimiento de dicho procedimiento para efectos contables, inclusive si el componente no se hubiera reconocido por separado.

Procede indicar que en la obra Las NIIF comentadas se señala que "(...) el importe dado de baja debe incluirse en la amortización (entiéndase depreciación) en lugar de clasificarse como una perdida por disposición porque el requerimiento es amortizar cada activo por separado” (KPMG, Las NIIF comentadas, 2012, pág. 337). 
Como consecuencia de dicho procedimiento, resulta necesario asignar un valor o importe a la parte o bien sustituido (es decir el elemento que se dará de baja), por lo cual se sugiere en la norma que podría considerarse como un indicativo el costo del elemento que se está incorporando como activo.

Debe tenerse en consideración que el importe a dar de baja corresponde al costo de la parte sustituida neta de su depreciación. Ello, implica que si se considera como indicativo el costo del bien que se está incorporando (reponiendo), también debe considerarse la depreciación respectiva.

El numeral 2.2. del Anexo 1: Definiciones Complementarias de la Directiva $\mathrm{N}^{\circ} 002$ 2016-EF/51.0128 señala que "cuando no se conozca el costo del elemento a sustituir, se podrá tomar como referencia el costo del nuevo elemento, descontando la depreciación acumulada7, para su baja respectiva (costo de reposición depreciado)'” (Resolucion Directoral, 2016, pág. 19).

7. La depreciación del componente sustituido, se aplicará sobre la base de una tasa relativa a la vida útil del mismo"

En consecuencia, en caso de que no se conozca el valor neto del componente que se debe dar de baja, corresponde realizar una estimación a efectos de la determinación del "costo de reposición depreciado".

Presentamos, a continuación, el ejemplo planteado por Bautista Mesa sobre la determinación del "costo de reposición depreciado", que resulta sumamente ilustrativo a efectos de apreciar el procedimiento contable y que se basa en estimar el valor neto que afectará a resultados.

\footnotetext{
${ }^{28}$ Dicha directiva aprueba el documento "Metodología para el reconocimiento, medición y registro de los bienes de Propiedades, planta y equipo de las Entidades Gubernamentales". https://www.mef.gob.pe/es/normatividadsp-2134/por-instrumentos/directivas/13922-05-rdn-006-2012-pip-transporte-estudios-en-paquete-mod-anexosnip-09-10-y-16-2-2-final-621/file, fecha de acceso 12 de enero 2020. Dicho tratamiento es acorde con la doctrina contable especializada.
} 


\section{E5.27. Renovaciones - Ejemplo}

Una empresa petrolera adquirió un buque por un importe de 1.000.000 u.m. cinco años atrás. La vida útil del buque se estima en 20 años, momento en el que debe ser desguazado. Tras la operación de desguace la empresa espera obtener un valor residual de 50.000 u.m.

La entidad tenía registrado el buque bajo un único epígrafe, sin separación de componentes, puesto que, en principio, todos estaban en condiciones de ser usados durante la vida útil total, de acuerdo con las especificaciones técnicas del armador.

Sin embargo, al comienzo del sexto año, se descubre un defecto en el motor principal que obliga a su sustitución. El nuevo motor es adquirido por un importe de 70.000 u.m. Se estima que los precios de este tipo de componentes han sufrido un incremento anual aproximado del $3 \%$. Se prevé que su vida útil sea únicamente de 15 años, exactamente igual a la vida útil restante del buque en ese momento, y que la incorporación del nuevo motor no afecte al valor residual inicialmente estimado para el activo.

Opinión:

(...). De acuerdo con lo anterior, el costo del motor antiguo se estimaría en:

Valor del motor antiguo $=\frac{70.000}{(1+3 \%)^{5}}=60.383$

Lo que representaría un 6,04 \% (60.383 / 1.000.000) del costo inicial del buque. Así pues,

la depreciación acumulada estimada para el motor sustituido ascendería a 14.341 [(1.000.000 $50.000) / 20 \times 5 \times 6,04 \%]$.

El registro contable de la renovación supone la baja del motor antiguo (...):

Db. Depreciación acumulada (motor antiguo) 14.341

Db. Pérdidas procedentes de Propiedades, planta y equipo 46.042

Cr. Propiedades, planta y equipo (motor antiguo)

60.383 (Bautista Mesa, 2015, págs. 105-106)

En el ejemplo mostrado, se aprecia que el saldo neto (S/ 46,042) del componente sustituido determinado en forma estimada afecta a resultados. En tal sentido, correspondería analizar cuál sería el efecto o incidencia tributaria sobre este tópico.

Similar tratamiento se brinda en el caso de las inspecciones generales. Es decir, cuando se produzca la siguiente inspección se reconocerá como costo del activo y de corresponder, se enviará a resultados el saldo por depreciar de la inspección previa, o si no se reconoció, se estimará su costo de reposición depreciado. Sobre este tópico, en la obra Insights Into IFRS, se desarrolla el ejemplo siguiente:

Ejemplo 15D-Coste de "Overhaul"- Compuesto dado de baja en cuentas 
3.2.280.15 Continuando con el ejemplo 15A, Compañía P lleva a cabo el dique seco de su barco después de dos años en vez de 3 años como estaba previsto originalmente. El valor contable del coste de revisión a la fecha es 27 (80/3). Los costes reales del dique seco son 100.

3.2.280.20 El valor contable restante del componente que ha sido reemplazado está cancelado inmediatamente porque el componente efectivamente se ha eliminado. La cantidad cancelada de 27 está incluida en la depreciación porque en efecto esta representa una revisión de la vida útil estimada del dique seco.

3.2.280.30 El coste real del dique seco de 100 esta capitalizado al coste del barco y depreciado sobre el periodo esperado hasta el siguiente dique seco. (KPMG, 2019, pág. 474)

\subsubsection{Análisis tributario}

La legislación del impuesto a la renta, tal como en extenso hemos analizado, no ha contemplado el reconocimiento inicial por componentes de un activo, pero sí ha previsto el reconocimiento como activo de los "costos posteriores" de acuerdo con las normas contables y que en algunos supuestos conlleva el reemplazo o sustitución de partes. Ello, en nuestra opinión, implicaría de suyo -cuando corresponda-también realizar la baja de aquellas partes que son sustituidas, ya que, de lo contrario, se estaría incrementando en forma indebida el costo del activo.

En la RTF 2977-5-2018, se analiza si la adquisición de componentes de una máquina tragamonedas para sustituir a los anteriores constituye costo o gasto. El Tribunal Fiscal emite su fallo que lo califica como "Costo" bajo el criterio siguiente:

(...) de lo afirmado por la recurrente en el sentido que "sin el kit de juegos las máquinas tragamonedas no pueden seguir funcionando, motivo por el cual debe ser reemplazado por uno que asegure el uso y funcionamiento de las máquinas tragamonedas por parte de los clientes, en caso sufra algún desperfecto que no sea posible de ser reparado y que además los referidos kit de juegos son adquiridos cuando el que se tiene en uso ha devenido en obsoleto o ya no genera el interés de los asistentes a la sala de juego por lo que deben ser reemplazados por otro kit que asegure el funcionamiento de la máquina tragamonedas, así de no efectuarse el cambio de kit la máquina

tragamonedas caería en desuso y tendría que ser retirada de la Sala de Juegos” (RTF, 2018).

Acorde con dicho sustento, es claro que los kits reemplazados deben darse de baja con la consecuente afectación de resultados. A mayor abundamiento, dichos bienes ya no pueden producir beneficios económicos futuros, que consideran que han devenido en obsoletos e inclusive podrían afectar al bien principal.

Por su parte, el artículo $43^{\circ}$ de la Ley del Impuesto a la Renta establece que en caso alguno de los bienes depreciables quedara fuera de uso u obsoleto, podrán, a opción del 
contribuyente, depreciarse anualmente hasta extinguir su costo o darse de baja, por el valor aún no depreciado a la fecha del desuso, debidamente comprobado.

Sobre el particular, en el inciso i) del artículo $22^{\circ}$ del Reglamento de la Ley del Impuesto a la Renta se establece que "el desuso o la obsolescencia deberán estar debidamente acreditados y sustentados con el informe técnico dictaminado por profesional competente y colegiado".

En nuestra opinión, este procedimiento se aplicaría cuando el activo principal queda obsoleto o fuera de uso, pero no propiamente para las partes o componentes de un activo. No obstante, aun cuando se considerase su aplicación a los componentes sustituidos y que, en tal supuesto, la única opción sería realizar la baja por el valor neto, surge el cuestionamiento respecto del procedimiento e importes por considerar para efectos de realizar la baja del componente sustituido.

Reiteramos que, para fines contables, la determinación del costo de las partes sustituidas se realiza siempre bajo costos estimados, ello inclusive cuando se hubiera, en un inicio, identificado el costo por separado del componente, ya que también es producto de una estimación. Supuesto no admitido para fines tributarios.

Consideramos que resultaría importante, que se modifique la legislación del impuesto a la renta y se incorpore en forma expresa el procedimiento para realizar la baja de los componentes o partes sustituidas, ello, con la finalidad, de otorgar seguridad jurídica a los contribuyentes y evitar controversias recurrentes entre estos y la administración tributaria.

\subsection{Depreciación de costos posteriores}

\subsubsection{Regulación tributaria y exposición de motivos}

El artículo 41 del TUO de la LIR, prescribe respecto de la depreciación de costos posteriores:

Artículo 41.- (...). En el caso de costos posteriores se tendrá en cuenta lo siguiente:

a) Se entiende por: 
(i) Costos iniciales: A los costos de adquisición, producción o construcción, o al valor de ingreso al patrimonio, incurridos con anterioridad al inicio de la afectación del bien a la generación de rentas gravadas.

(ii) Costos posteriores: A los costos incurridos respecto de un bien que ha sido afectado a la generación de rentas gravadas y que, de conformidad con lo dispuesto en las normas contables, se deban reconocer como costo.

b) El porcentaje anual de depreciación o el porcentaje máximo de depreciación, según corresponda a edificios o construcciones u otro tipo de bienes, se aplicará sobre el resultado de sumar los costos posteriores con los costos iniciales, (...)

c) El importe resultante de lo dispuesto en el literal anterior será el monto deducible o el máximo deducible en cada ejercicio gravable, según corresponda, salvo que en el último ejercicio el importe deducible sea mayor que el valor del bien que quede por depreciar, en cuyo caso se deducirá este último.

En virtud del procedimiento regulado en la LIR, la depreciación que resulta aceptable debe calcularse sobre los costos iniciales más los costos posteriores del activo como un único bien, encontrarse contabilizada y no exceder el porcentaje máximo tributario o el porcentaje fijo (en el caso de edificaciones).

Corresponde señalar que este artículo fue modificado por el decreto legislativo $\mathrm{N}^{\circ} 1112$, vigente a partir del 01.01.2013. Al respecto, en la exposición de motivos se expone respecto de la depreciación del valor de las mejoras ${ }^{29}$, la problemática en virtud de la cual se sustentó:

(...) surge debido a que si bien el artículo 41 de la Ley señala la base sobre la cual se calculará la depreciación en el caso de mejoras incorporadas con carácter permanente, la norma no ha indicado la forma en que esta se aplica en diferentes supuestos, como cuando el bien al que se incorpora la mejora está totalmente depreciado o cuando dicha mejora prolonga el plazo de depreciación o genera diferencias entre los importes depreciables de algunos ejercicios.

También en la exposición de motivos, se grafica la modificatoria a través del ejemplo siguiente:

\begin{tabular}{|l|l|l|l|}
\hline Ejercicio & Costo de adquisición & Costo posterior & $\begin{array}{l}\text { Monto de depreciación } \\
\text { tributaria deducible * }\end{array}$ \\
\hline 1 & 100 & & 20 \\
\hline 2 & 100 & & 20 \\
\hline 3 & 100 & 40 & $28 * *$ \\
\hline 4 & 100 & 40 & $28 * *$ \\
\hline 5 & 100 & 40 & $28 * *$ \\
\hline 6 & & 40 & $16 * * *$ \\
\hline & & & 140 \\
\hline
\end{tabular}

* Para efectos del presente ejemplo, se asume una tasa máxima de depreciación anual de 20\%.

${ }^{29}$ Término utilizado en la legislación vigente hasta el ejercicio 2012. 
** Resultado de aplicar la tasa de depreciación anual de $20 \%$ sobre el valor de adquisición más el costo posterior: $20 \%(100+40)=28$

*** Aun cuando el resultado de aplicar la tasa de depreciación anual sobre el valor de adquisición más el costo posterior sea de 28, solo se podrá deducir el saldo del valor del activo fijo que queda por depreciar $=16$.

Acorde al procedimiento regulado y este ejemplo, la depreciación del costo posterior no debe exceder -bajo ningún supuesto- del porcentaje máximo fijado en cada año (no aplicable a edificaciones). Por lo que la depreciación contabilizada deberá compararse con dicho tope a fin de establecer la depreciación aceptable.

Un aspecto que genera cuestionamientos sería si debiera determinarse el "último ejercicio" en función del activo principal o al costo posterior. Ello, dado que en el ejemplo planteado, el "último ejercicio" es el año 6 que considera que en este se imputa el saldo pendiente de depreciar. No obstante, debe considerarse lo siguiente:

a) En función del activo principal, el año 5 es el último ejercicio.

b) En función solo al costo posterior, si también se deprecia en función del $20 \%$ máximo, el "último ejercicio" sería el año 7 y no el año 6.

Bajo la consideración que, tanto al costo inicial como al costo posterior, no se le puede aplicar un porcentaje mayor al máximo permitido o fijo si es edificaciones, el "último ejercicio" debería corresponder al año 7 , respecto del costo posterior.

A mayor abundamiento, en la llamada “***” que corresponde al ejercicio 6 se señala que la depreciación anual es de " 28 " y, por ello, se puede deducir " 16 ". Sin embargo, en ese ejercicio, la depreciación anual máxima calculada sobre el costo posterior solo corresponde a "8".

Finalmente, téngase en consideración que, en la problemática detallada y ejemplo planteado, no se considera el supuesto de la baja de las partes sustituidas.

\subsubsection{Análisis contable y efecto tributario}

Se aprecia que, propiamente, este procedimiento determinado para los casos en los que surjan costos posteriores difiere del requerido en las normas contables. Así, para fines 
contables se determina la nueva base depreciable y luego se calcula la depreciación en función de la vida útil restante. Inclusive, debe disminuirse el costo estimado de las partes que son sustituidas o reemplazadas en los casos que ello ocurra.

Así, un ejemplo típico en el cual se produce la sustitución o reemplazo de un costo previo corresponde al supuesto de inspecciones generales o grandes reparaciones. Bautista Mesa, sobre el particular, señala que "las inspecciones generales de Propiedades, planta y equipo son manifestaciones de la contabilidad de componentes que implica diferentes cuotas de depreciación para reconocer de forma separada el gasto correspondiente a las reparaciones significativas que permiten que el resto del activo sea utilizado durante toda su vida útil" (Bautista Mesa, 2015, pág. 103).

Presentamos la segunda parte del ejemplo desarrollado en el numeral 1.4.1. que ilustra sobre el cálculo de la depreciación contable cuando se produce un costo posterior que ha implicado la baja de partes sustituidas:

\section{E5.27. Renovaciones - Ejemplo}

Una empresa petrolera adquirió un buque por un importe de 1.000.000 u.m. cinco años atrás. La vida útil del buque se estima en 20 años, momento en el que debe ser desguazado. Tras la operación de desguace la empresa espera obtener un valor residual de 50.000 u.m.

La entidad tenía registrado el buque bajo un único epígrafe, sin separación de componentes, puesto que, en principio, todos estaban en condiciones de ser usados durante la vida útil total, de acuerdo con las especificaciones técnicas del armador.

Sin embargo, al comienzo del sexto año, se descubre un defecto en el motor principal que obliga a su sustitución. El nuevo motor es adquirido por un importe de 70.000 u.m. Se estima que los precios de este tipo de componentes han sufrido un incremento anual aproximado del $3 \%$. Se prevé que su vida útil sea únicamente de 15 años, exactamente igual a la vida útil restante del buque en ese momento, y que la incorporación del nuevo motor no afecte al valor residual inicialmente estimado para el activo.

Opinión:

El tratamiento posterior a la renovación dependerá de la estimación de vida útil y valor residual del nuevo elemento incorporado. En general, el nuevo motor estará en uso a lo largo de la vida útil restante del buque, por lo que deberá ser depreciado de acuerdo con este plazo remanente. De esta forma, la nueva cuota de depreciación del buque se calcularía de la siguiente forma:

- Importe bruto del buque después de la sustitución: $1.000 .000-\underline{60.383}+70.000=1.009 .617$

- Depreciación acumulada después de la sustitución: [(1.000.000 - 50.000)/20 x 5] $-\underline{14.341}=$ 223.159

- Valor depreciable: [(1.009.617 - 50.000) - 223.159] = 736.458

- Vida útil restante: 15 años

- Nueva cuota de depreciación: 736.458 / $15=49.097$

No obstante, la entidad podría estimar una vida útil inferior y tratar el nuevo elemento 
incorporado por separado de forma similar a una gran reparación. (Bautista Mesa, 2015, págs. 105106)

En el ejemplo, el motor nuevo no se trata como un componente distinto, dado que tiene una vida útil estimada similar al activo principal. En función de ello, se determina la nueva base depreciable del activo y se considera la deducción de los valores de S/ 60,383 y S/ 14,341 que corresponden al costo y depreciación estimados- respectivamente - del motor antiguo que se ha dado de baja, lo cual conlleva que el valor depreciable sea estimado.

Apreciamos, en tal sentido, que debería realizarse el cálculo vía papeles de trabajo en función del procedimiento regulado en el artículo 41 del TUO de la LIR y compararlo con la depreciación contabilizada a efectos de establecer la depreciación aceptable tributariamente. No obstante, la baja de las partes sustituidas no se encuentra regulada y por lo tanto, tampoco se tiene certeza respecto del "costo inicial" para fines tributarios a considerar después de la sustitución.

Así, obsérvese que, de acuerdo al enunciado planteado, se tienen los datos siguientes:

a) Costo inicial $=1.000 .000 \mathrm{u} . \mathrm{m}$

b) Costo posterior (nuevo motor) $=70.000 \mathrm{u} . \mathrm{m}$.

En nuestra opinión, no se podría considerar la sumatoria de ambos conceptos como la base depreciable para fines tributarios, dado que se ha producido la baja del motor antiguo.

\subsubsection{Costo posterior o nuevo activo}

En virtud de lo desarrollado en el presente trabajo de investigación, para fines tributarios, la depreciación se efectúa en función del activo principal y no por componentes. Además, cuando se produce un desembolso posterior que califica como "costo", corresponde que se sume a los "costos iniciales" para determinar la base depreciable y, en función de ello, calcular su depreciación de acuerdo con lo previsto en el artículo 41 TUO LIR y que hemos desarrollado en el subnumeral 1.5.1 anterior.

En consecuencia, resulta relevante, adicionalmente, definir que un desembolso califica como activo, se identifique en forma adecuada si constituye un nuevo activo o por el contrario un costo posterior, ello a fin de evitar incurrir en contingencias tributarias. Obsérvese que, si 
se considera un nuevo activo, inclusive podría resultar diferente el porcentaje de depreciación fijo o máximo permitido.

En la RTF 919-1-2019 (RTF, 2019), se analiza si los desembolsos siguientes: "sistemas de iluminación, sistemas de intrusión (alarmas), sistemas eléctricos, sistemas de protección contra incendios, sistemas de climatización, escaleras eléctricas, instalaciones sanitarias, entre otros" califican como instalaciones fijas y permanentes (criterio de la administración tributaria) o, por el contrario, constituyen bienes muebles distintos (criterio del contribuyente).

En dicha resolución, se señala que "la discusión se centra en determinar si los activos fijos observados que fueron incorporados en los locales en los que la recurrente desarrolla sus actividades comerciales deben depreciarse con la tasa anual prevista para los edificios y construcciones, esto es, el 5\%”. Este era el criterio esgrimido por la administración tributaria.

El Tribunal Fiscal vierte la conclusión siguiente:

(...) los activos fijos observados son instalaciones fijas y permanentes que forman parte integrantes de las edificaciones en las que la recurrente desarrolla sus actividades comerciales, les resulta aplicable la tasa de depreciación tributaria correspondiente a los edificios y construcciones (5\%).

Por tanto, se confirma el reparo formulado por Sunat y repara la depreciación en exceso a la máxima permitida tributariamente.

\subsection{Análisis comparativo: Financiero vs. Tributario}

\begin{tabular}{|c|c|c|c|c|c|}
\hline \multirow[t]{2}{*}{ Concepto } & \multicolumn{2}{|c|}{ Financieramente } & \multicolumn{2}{|c|}{ Tributariamente } & \multirow[t]{2}{*}{ Efecto } \\
\hline & $\begin{array}{l}\text { Tratamiento de } \\
\text { los desembolsos }\end{array}$ & Depreciación & $\begin{array}{l}\text { Tratamiento de } \\
\text { los desembolsos }\end{array}$ & Depreciación & \\
\hline $\begin{array}{l}\text { Reconocimi } \\
\text { ento inicial }\end{array}$ & $\begin{array}{l}\text { Deben } \\
\text { cumplir } \\
\text { definición y } \\
\text { principio de } \\
\text { reconocimie } \\
\text { nto según } \\
\text { NIIF } 16 .\end{array}$ & $\begin{array}{l}\text { La depreciación } \\
\text { se inicia a partir } \\
\text { que el bien se } \\
\text { encuentra en la } \\
\text { condición y } \\
\text { ubicación } \\
\text { necesarias para } \\
\text { operar según lo } \\
\text { previsto por la } \\
\text { gerencia. } \\
\text { La depreciación } \\
\text { se realiza de } \\
\text { acuerdo con la } \\
\text { vida útil }\end{array}$ & $\begin{array}{l}\text { Deben } \\
\text { cumplir } \\
\text { definición y } \\
\text { principios de } \\
\text { reconocimien } \\
\text { to según NIIF } \\
16 \text { Bajo } \\
\text { aplicación } \\
\text { supletoria en } \\
\text { tanto no se } \\
\text { oponga a lo } \\
\text { previsto en la } \\
\text { LIR. }\end{array}$ & $\begin{array}{l}\text { La } \\
\text { depreciación } \\
\text { se inicia a } \\
\text { partir que el } \\
\text { bien se destina } \\
\text { a la generación } \\
\text { de rentas } \\
\text { gravadas. }\end{array}$ & $\begin{array}{l}\text { Posibles diferencias } \\
\text { temporales: } \\
>\text { Materialidad } \\
\text { financiera vs. 1/4 } \\
\text { UIT. } \\
>\text { Inicio de la } \\
\text { depreciación } \\
\text { Depreciación } \\
\text { contable } \\
\text { depreciación vs. } \\
\text { máxima permitida } \\
\text { o 5\% en el caso de } \\
\text { edificaciones. }\end{array}$ \\
\hline
\end{tabular}




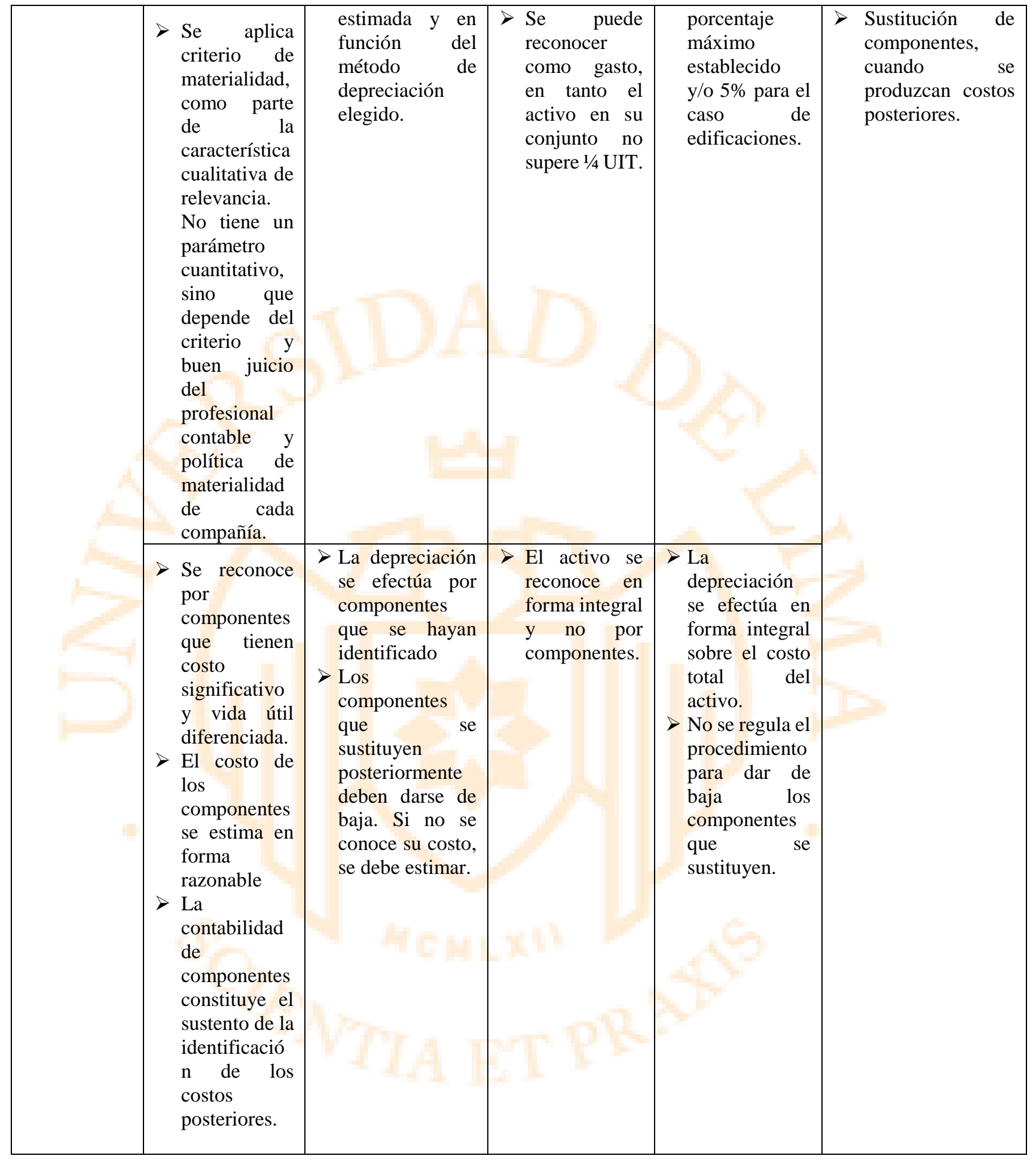




\begin{tabular}{|c|c|c|c|c|c|}
\hline \multirow[t]{3}{*}{$\begin{array}{l}\text { Costos } \\
\text { posteriores }\end{array}$} & $\begin{array}{l}\mathrm{Se} \text { aplica } \\
\text { principio de } \\
\text { reconocimie } \\
\text { nto } \\
\text { contemplado } \\
\text { en la NIC } 16 .\end{array}$ & \multirow[t]{3}{*}{$\begin{array}{l}\text { Vía } \\
\text { depreciación. } \\
\text { Vía la baja de } \\
\text { componentes } \\
\text { que se } \\
\text { sustituyen. }\end{array}$} & \begin{tabular}{|l} 
Se aplican \\
normas \\
contables por \\
remisión \\
expresa. \\
$>$ No se \\
contempla \\
una \\
regulación \\
tributaria \\
diferenciada \\
para \\
supuestos \\
específicos. \\
Procedería \\
aplicar \\
principios de \\
legislación \\
general, en \\
caso de \\
conflicto con \\
normas \\
contables.
\end{tabular} & \multirow{3}{*}{$\begin{array}{l}\text { Vía } \\
\text { depreciación } \\
\text { Procede la } \\
\text { baja en el caso } \\
\text { de costos } \\
\text { previos } \\
\text { realmente } \\
\text { incurridos y } \\
\text { que se puedan } \\
\text { identificar. } \\
\text { No se regula, } \\
\text { la baja de } \\
\text { componentes } \\
\text { que se } \\
\text { sustituyen, en } \\
\text { caso su costo } \\
\text { sea estimado. }\end{array}$} & \multirow{3}{*}{$\begin{aligned} & \text { Posibles diferencias } \\
& \text { temporales: } \\
&> \text { Materialidad } \\
& \text { financiera } \\
&> \text { Depreciación } \\
& \text { contable vs. } \\
& \text { depreciación } \\
& \text { máxima permitida } \\
& \text { o } 5 \% \text { en el caso de } \text { edificaciones. } \\
&> \text { Sustitución de } \\
& \text { componentes, } \\
& \text { cuando } \\
& \text { produzcan costos } \\
& \text { posteriores }\end{aligned}$} \\
\hline & $\begin{array}{l}\text { Se aplica } \\
\text { criterio de } \\
\text { materialidad } \\
\text { para su } \\
\text { reconocimie } \\
\text { nto. }\end{array}$ & & \begin{tabular}{|l} 
No procede \\
aplicar a los \\
costos \\
posteriores, el \\
parámetro \\
cuantitativo \\
del $1 / 4$ UIT.
\end{tabular} & & \\
\hline & $\begin{array}{l}\text { Pueden } \\
\text { existir } \\
\text { componentes } \\
\text { físicos y } \\
\text { componentes } \\
\text { no físicos. }\end{array}$ & & \begin{tabular}{|l} 
No se \\
reconocen por \\
componentes, \\
sino como \\
costo \\
adicional del \\
activo \\
principal. \\
Ello, acorde \\
al artículo 41 \\
TUO LIR.
\end{tabular} & & \\
\hline $\begin{array}{l}\text { Costos } \\
\text { posteriores } \\
- \\
\text { Component } \\
\text { es físicos } \\
\text { (adición, } \\
\text { mejora, } \\
\text { reconstrucc } \\
\text { ión, } \\
\text { reemplazos) }\end{array}$ & $\begin{array}{l}\text { Deben cumplir } \\
\text { principio de } \\
\text { reconocimient } \\
\text { o según NIC } \\
16 \text {. }\end{array}$ & $\begin{array}{l}\text { Se deprecian } \\
\text { desde que se } \\
\text { encuentran en } \\
\text { la ubicación y } \\
\text { condiciones } \\
\text { necesarias para } \\
\text { operar de } \\
\text { acuerdo con lo } \\
\text { previsto por } \\
\text { gerencia. }\end{array}$ & $\begin{array}{l}\text { Califican como } \\
\text { costo posterior, } \\
\text { entendemos si } \\
\text { cumple } \\
\text { principio de } \\
\text { reconocimiento } \\
\text { según NIC 16, } \\
\text { por remisión } \\
\text { expresa. }\end{array}$ & $\begin{array}{ll}\text { Se deprecian } \\
\text { desde que se } \\
\text { destinan a la } \\
\text { generación } & \text { de } \\
\text { rentas } & \\
\text { gravadas. } & \end{array}$ & $\begin{array}{l}\text { Posibles Diferencias } \\
\text { Temporales } \\
>\text { Inicio de la } \\
\text { depreciación } \\
>\text { Costos estimados } \\
>\text { Depreciación por } \\
\text { componentes vs. } \\
\text { depreciación } \\
\text { máxima }\end{array}$ \\
\hline
\end{tabular}




\begin{tabular}{|c|c|c|c|c|c|}
\hline & $\begin{array}{l}\text { Si su costo es } \\
\text { significativo y } \\
\text { tienen vida útil } \\
\text { diferenciada, } \\
\text { se } \\
\text { reconocerían } \\
\text { como un } \\
\text { componente } \\
\text { separado. Para } \\
\text { ello, se efectúa } \\
\text { una estimación } \\
\text { del costo. }\end{array}$ & $\begin{array}{lr}\mathrm{Si} & \text { se } \\
\text { identifican } & \\
\text { como } & \\
\text { componentes } & \\
\text { separados, } & \text { se } \\
\text { deprecian } & \text { en } \\
\text { función de } & \text { su } \\
\text { vida } & \text { útil } \\
\text { estimada } & \\
\text { Si no } & \text { se } \\
\text { reconoce como } & \\
\text { costo } & \\
\text { separado, } & \text { se } \\
\text { integra } & \text { al } \\
\text { "resto" } & \text { del } \\
\text { activo y } & \text { se } \\
\text { deprecia } & \text { en } \\
\text { función de la } & \text { la } \\
\text { vida } & \text { útil } \\
\text { restante. } & \\
\end{array}$ & $\begin{array}{l}\text { No se admite } \\
\text { la } \\
\text { identificación } \\
\text { por } \\
\text { componentes } \\
\text { ni la } \\
\text { estimación de } \\
\text { su valor. }\end{array}$ & $\begin{array}{l}\text { La } \\
\text { depreciación se } \\
\text { efectúa sobre la } \\
\text { base } \\
\text { depreciable y } \\
\text { observando que } \\
\text { no exceda el } \\
\text { porcentaje } \\
\text { máximo } \\
\text { permitido. }\end{array}$ & $\begin{aligned} & \text { permitida o } 5 \% \\
& \text { para } \\
& \text { edificaciones. } \\
&> \text { Baja de piezas } \\
& \text { que se sustituyen } \\
&> \text { Costo estimado } \\
& \text { luego de la baja. }\end{aligned}$ \\
\hline & $\begin{array}{l}\text { La base } \\
\text { depreciable } \\
\text { luego del costo } \\
\text { posterior se } \\
\text { puede ver } \\
\text { incidida por el } \\
\text { costo estimado } \\
\text { de las partes } \\
\text { que se dan de } \\
\text { baja. }\end{array}$ & $\begin{array}{l}\text { Se debe dar de } \\
\text { baja a las } \\
\text { partes que se } \\
\text { sustituyen. Si } \\
\text { no se conoce } \\
\text { su costo, se } \\
\text { efectúa una } \\
\text { estimación. }\end{array}$ & \begin{tabular}{|lr} 
El & costo \\
posterior se & \\
suma al valor \\
del activo \\
principal. \\
Base \\
depreciable = \\
Costos \\
iniciales + \\
costos \\
posteriores.
\end{tabular} & $\begin{array}{l}\text { No se regula el } \\
\text { procedimiento } \\
\text { a aplicar en el } \\
\text { caso de la baja } \\
\text { de las partes o } \\
\text { componentes } \\
\text { que se } \\
\text { sustituyen. }\end{array}$ & \\
\hline $\begin{array}{l}\text { Component } \\
\text { es no físicos } \\
\text { (inspeccione } \\
\text { s generales, } \\
\text { grandes } \\
\text { reparacione } \\
\text { s) }\end{array}$ & \begin{tabular}{|lr} 
Se debe & estimar \\
diferenciar & \\
desde & la \\
oportunidad & \\
del & \\
reconocimient \\
o inicial del \\
activo. \\
Deben cumplir \\
principio de \\
reconocimient \\
o según NIC \\
16. \\
Siempre se \\
reconocen \\
como un \\
componente \\
separado (al \\
inicio \\
posteriormente \\
) y
\end{tabular} & $\begin{array}{l}\text { Su } \\
\text { depreciación } \\
\text { se inicia desde } \\
\text { que el activo } \\
\text { con el cual se } \\
\text { vincula se } \\
\text { encuentra en la } \\
\text { ubicación y } \\
\text { condiciones } \\
\text { necesarias para } \\
\text { operar de } \\
\text { acuerdo con lo } \\
\text { previsto por } \\
\text { gerencia. } \\
\text { Se deprecian } \\
\text { en función del } \\
\text { tiempo } \\
\text { estimado para } \\
\text { que se realice } \\
\text { próxima gran } \\
\text { reparación. } \\
\text { En la } \\
\text { oportunidad }\end{array}$ & \begin{tabular}{|l} 
En el \\
reconocimiento \\
inicial del \\
activo, no se \\
contempla la \\
identificación \\
de este tipo de \\
componente. \\
Calificarían \\
como costo \\
posterior bajo \\
la aplicación de \\
la NIC 16, \\
entendemos si \\
cumple \\
principio de \\
reconocimiento \\
por remisión \\
expresa. \\
No se admite \\
la \\
identificación
\end{tabular} & \begin{tabular}{|l} 
La \\
depreciación se \\
inicia desde \\
que se destinan \\
a la generación \\
de rentas \\
gravadas. \\
La \\
depreciación se \\
efectúa sobre la \\
base \\
depreciable y \\
observando que \\
no exceda el \\
porcentaje \\
máximo \\
permitido. \\
No se regula el \\
procedimiento \\
a aplicar en el \\
caso de la baja \\
de las partes o \\
componentes
\end{tabular} & $\begin{array}{l}\text { Posibles Diferencias } \\
\text { Temporales } \\
>\text { Inicio de la } \\
\text { depreciación } \\
>\text { Costo estimado } \\
\text { inicial } \\
>\text { Depreciación por } \\
\text { componentes vs. } \\
\text { depreciación } \\
\text { máxima } \\
\text { permitida o } 5 \% \\
\text { para } \\
\text { edificaciones. } \\
>\text { Baja del costo } \\
\text { estimado de la } \\
\text { inspección } \\
\text { previa. } \\
\text { Costo estimado } \\
\text { luego de la baja. }\end{array}$ \\
\hline
\end{tabular}




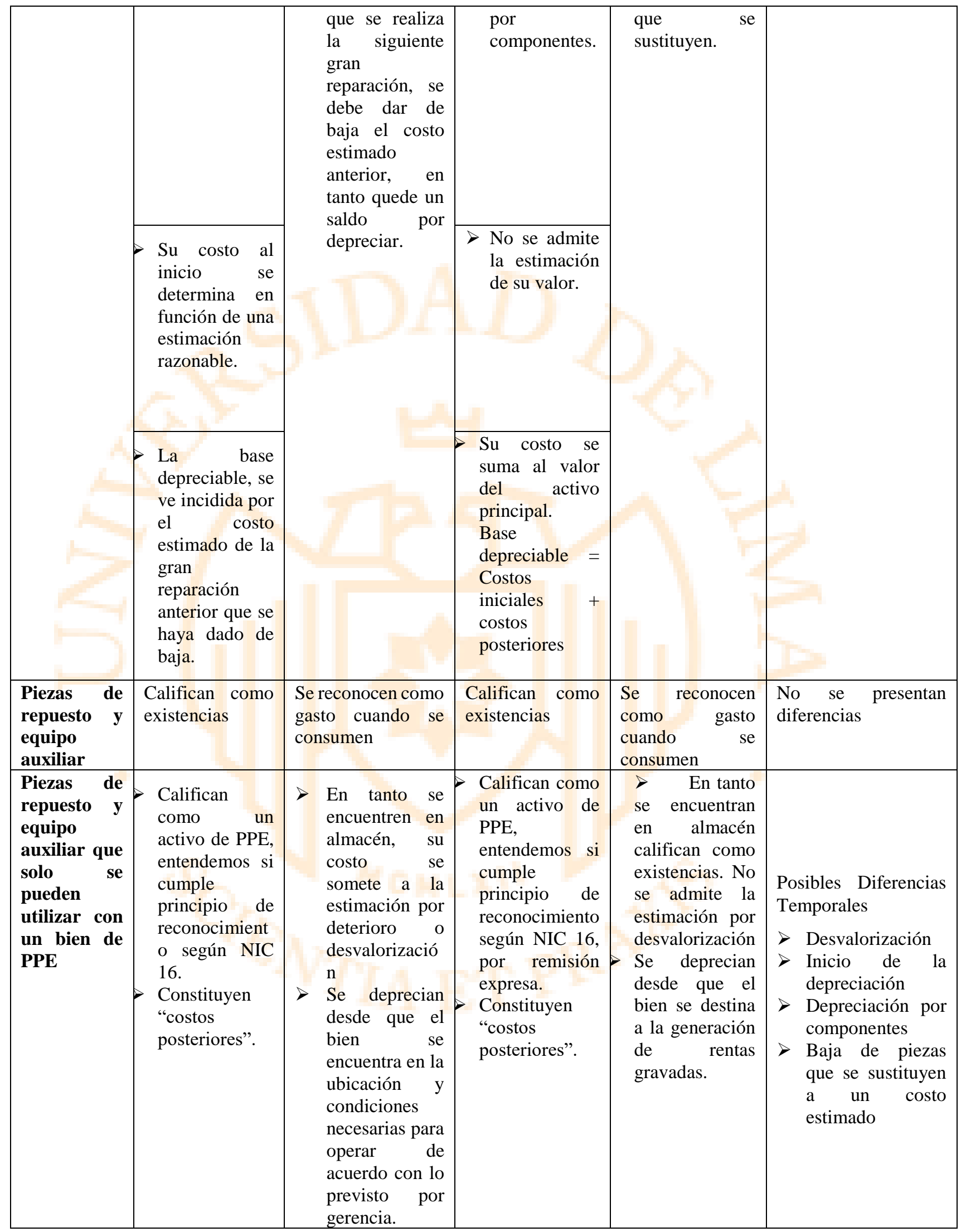




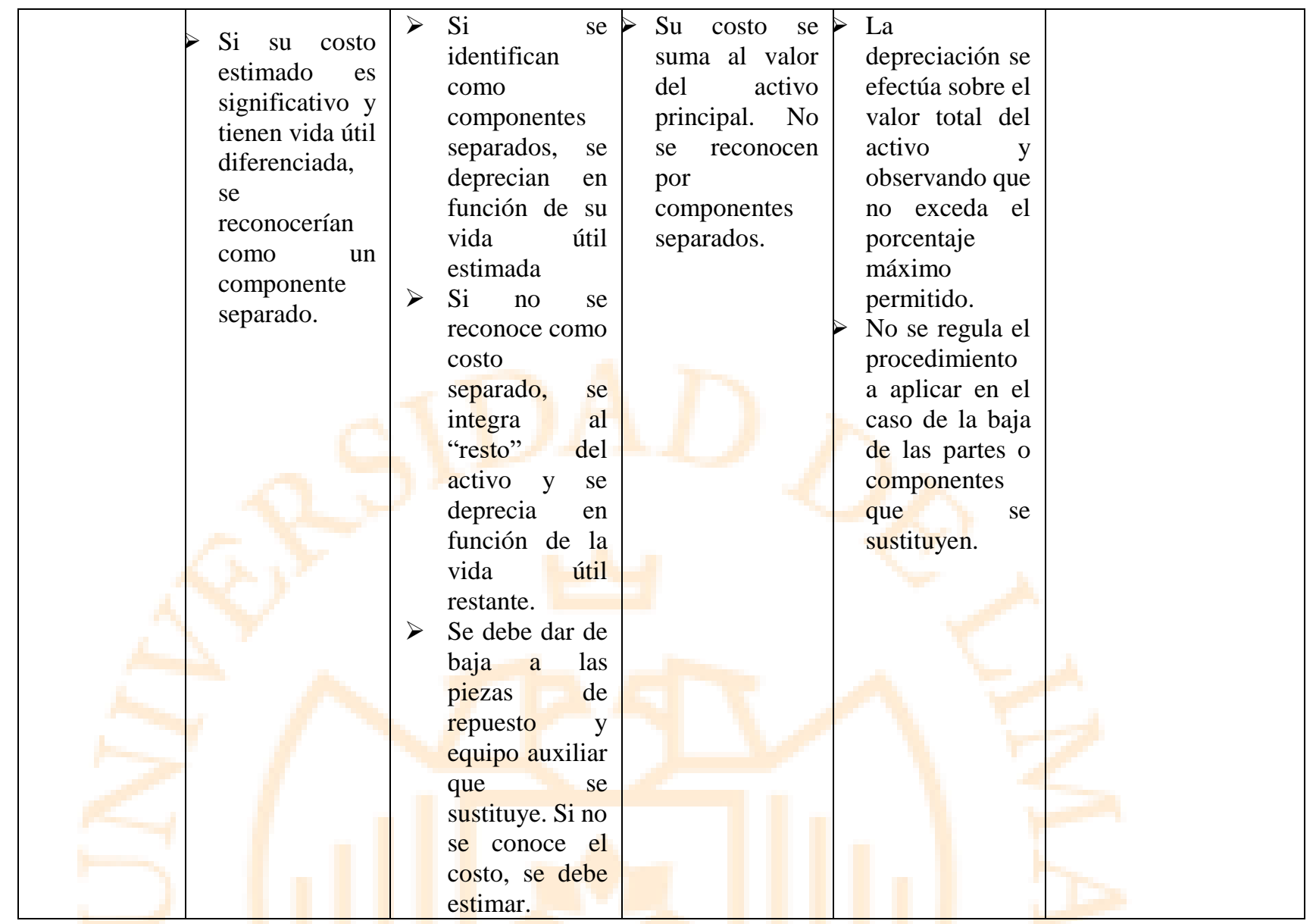




\section{Capítulo IV: CONCLUSIONES}

1. Para fines tributarios, la interpretación de los conceptos contables debe fundamentarse en las NIIF que hayan sido oficializadas por la respectiva resolución del CNC.

2. Las NIIF por aplicarse, en nuestra opinión, deben corresponder a la versión vigente en cada ejercicio gravable salvo expresa disposición de la legislación del impuesto a la renta.

3. A partir del ejercicio 2013 -en virtud del D. Leg. 1112- se sustituye en los artículos 20, 41 y 44 e) de la Ley del Impuesto a la Renta el término "mejoras de carácter permanente" por el concepto de "costos posteriores".

4. La definición tributaria de "costos posteriores" corresponde a "los costos incurridos respecto de un bien que ha sido afectado a la generación de rentas gravadas (...) que deben ser reconocidos como costo según lo dispuesto en las normas contables". De esta manera, se efectúa una remisión expresa a las normas contables a efectos de identificar en qué supuestos los desembolsos posteriores deben calificar como "costo" bajo una fórmula legal abierta sin restricciones o límites.

5. De acuerdo con la NIC 16, para que un desembolso posterior califique como "activo", debe cumplir con el principio de reconocimiento previsto en el párrafo 7 y que implica los requisitos siguientes: (i) probabilidad de obtener beneficios económicos futuros y 
(ii) el costo se pueda medir fiablemente. Ello involucra la aplicación de estimaciones y juicios o criterios profesionales como se ha desarrollado en la doctrina contable.

6. En nuestra opinión, la modificación tributaria no consideró a detalle los diferentes supuestos que pueden presentarse bajo las NIIF, así como doctrina contable y que, en determinadas circunstancias, podría resultar opuesto o contradictorio con el marco previsto en la legislación del impuesto a la renta. Así, la aplicación de juicios, criterios y estimaciones responden a supuestos no admitidos dado que son de carácter subjetivo.

7. Para efectos contables, se requiere que el costo del activo, en el reconocimiento inicial, se asigne a sus partes significativas que tengan una vida útil diferente. Ello se denomina "reconocimiento por componentes" o "componetización" e impacta en la depreciación, así como en los reemplazos o sustituciones cuando se produzcan costos posteriores. Para efectos tributarios, no se contempla este tipo de reconocimiento, sino se considera el reconocimiento respecto de un único activo.

8. En la práctica, surgen diversas y diferentes controversias entre los contribuyentes y la Sunat a efectos de determinar si un desembolso inicial o posterior constituye costo o gasto, aun cuando ambas partes aplican la NIC 16. Ello, dado que aplican un criterio o análisis diferente, respecto justamente del cumplimiento del principio de reconocimiento.

9. El Tribunal Fiscal, en algunas resoluciones que resuelven controversias sobre "costos posteriores" versus "gasto" correspondientes a ejercicios gravables vigentes a partir del ejercicio 2013, formula su análisis y emite su criterio bajo la consideración de “mejoras permanentes" lo cual resulta opuesto a la legislación tributaria vigente.

10. Los desembolsos posteriores, según su naturaleza o características, se podrán incorporar como parte del importe en libros de un activo existente como el supuesto de la sustitución de componentes o se considerarán como un activo nuevo. De acuerdo 
con la NIC 16, resulta obligatorio dar de baja a las partes o componentes que se sustituyen siendo el costo estimado.

11. La legislación tributaria no ha regulado el procedimiento para realizar la baja de las partes o componentes que se sustituyen ni tampoco cómo efectuar su medición cuando no se conoce su valor. Debe tenerse en consideración, que la estimación realizada para fines contables no resulta admitida.

12. La depreciación de los costos posteriores regulada en el artículo 41 de la LIR difiere de la requerida en las normas contables. Así, para fines contables se determina la nueva base depreciable y luego se calcula la depreciación en función de la vida útil restante. Inclusive, debe disminuirse el costo estimado de las partes que son sustituidas o reemplazadas en los casos que ello ocurra.

13. Resultaría importante que se modifique la legislación del impuesto a la renta y se incorpore, en forma expresa, el procedimiento para realizar la baja de los componentes o partes sustituidas, ello con la finalidad de otorgar seguridad jurídica a los contribuyentes y evitar controversias recurrentes entre estos y la administración tributaria. 


\section{REFERENCIAS: AUTORES E INSTITUCIONES}

Bautista Mesa, R. (2015). Propiedades, planta y equipo. Colombia. Obtenido de http://www.ctcp.gov.co/publicaciones-ctcp/orientaciones-tecnicas/1472852022-9340, fecha de acceso 28 de octubre de 2019.

Bravo Cucci, J. (2014). La contabilidad como fuente del derecho. Peru, Perú: Thomson Reuters.

Calzada Mezura, M. (2011). Capitalización de costos. Revista Contaduría pública del instituto mexicano de contadores públicos. Obtenido de http://contaduriapublica.org.mx/2011/06/06/capitalizacion-de-costos/ fecha de acceso: 31 de octubre de 2019 .

Colegio de Contadores de Chile. (s.f.). Tratamiento contable del activo fijo. Boletín Técnico Nro. 33. Obtenido de http://rmcontadores.cl/wpcontent/files_mf/1484098310BoletinN33.pdf, fecha de acceso 12 de enero de 2020.

Direccion Nacional de Contabilidad Publica. (s.f.). Ministerio de Economia y Finanzas. Obtenido de Propiedad, planta y equipo: https://www.mef.gob.pe/es/preguntasfrecuentes-sp-10033/propiedad-planta-y-equipo, fecha de acceso: 12 de enero de 2020.

Editorial Economia y Finanzas. (s.f.). Apéndice de jurisprudencia en línea. Obtenido de https://www.eef.com.pe/verapendice.php?id=n\$cW61rFA:7Iq\$0MqmT1tA\&keyword $=9478$, fecha de acceso 1 de diciembre de 2019 . 
Fundación IFRS (2014). Material didáctico sobre las NIIF basado en el Marco Conceptual. Etapa 1- Propiedades, Planta y Equipo. Obtenido de: http://www.nicniif.org/home/descargar-documento/1883-etapa-1.-propiedadesplanta-y-equipo.html, fecha de acceso 5 de noviembre 2019.

Instituto de Contabilidad y Auditoria de Cuentas de España. (1 de marzo de 2013). Normas de registro y valoración del inmovilizado material y de las inversiones inmobiliarias. Boletín Oficial del Estado Nro. 58. Obtenido de http://www.icac.meh.es/Normativa/Contabilidad/Nacional/ficha.aspx?hid=66, fecha de acceso 15 de enero de 2020.

Kieso, D., \& Weygandt, J. (1999). Contabilidad intermedia. En Limusa S.A. (Ed.). México, México.

KPMG. (2012). Guía práctica para comprender las Normas Internacionales de Información Financiera. Las NIIF comentadas. España, España: Thomson Reuters - Aranzadi.

KPMG. (2019). Insights into IFRS. KPMG's practical guide to IFRS standards. Volume 116. Italia, Italia:Thomson Reuters.

Manzano Albor, E. (2007). Valoración y registro del inmovilizado material según las Normas Internacionales de Contabilidad del IASB: NIC 16. CES Felipe II, Revista Enlaces, 7, España: Universidad Complutense de Madrid. Obtenido de http://www.cesfelipesegundo.com/revista/articulos2007b/Manzano\%20Albor_corregid o.pdf, fecha de acceso 05.11.2019.

Otal, S., \& Serrano, R. (2006). Reconocimiento y valoración de los activos fijos no financieros en las NIIF. Saberes, revista de estudios jurídicos, económicos y sociales 4, España: 
Universidad Alfonso $\quad X \quad$ El Sabio. Obtenido de https://revistas.uax.es/index.php/saberes/article/view/783/739, fecha de acceso 05.11.2019.

Romero, J. (1996). Contabilidad intermedia. México: Interamericana editores S.A.

Valiente, J. (2004). Teoría de la Contabilidad Financiera. España: Ediciones Académicas S.A.

\section{REFERENCIAS: NORMAS LEGALES}

Congreso de la Republica. (01 de enero de 1997). Ley N²6887. Peru.

Conasev. (19 de Octubre 2010). Resolución N 102-2010-EF/94.01.1

Consejo Normativo de Contabilidad. (02 de marzo de 2005). Resolución № 034-2005EF/93.01. Peru.

Consejo Normativo de Contabilidad. (23 de julio de 1998). Resolución N 013-98-EF/93.01. Peru.

Consejo Normativo de Contabilidad. (29 de agosto de 2018). Resolución N 002-2018-EF/30. Peru.

Consejo Normativo de Contabilidad. (24 de mayo 2019). Resolución N 002-2019-EF/30. Peru. 
Consejo Normativo de Contabilidad. (21 de setiembre de 2019). Resolución N 003-2019EF/30. Peru.

Ministerio de Economía y Finanzas. (21 de setiembre de 1994). Decreto Supremo N. ${ }^{\circ} 122-$ 1994-EF. Reglamento de la Ley del Impuesto a la Renta. Peru.

Ministerio de Economía y Finanzas. (2002). Decreto Supremo Nro. 093-2002-EF. Ley de Mercado de Valores. Peru.

Ministerio de Economía y Finanzas. (8 de diciembre de 2004). Decreto Supremo N. ${ }^{\circ}$ 1792004-EF. Ley del Impuesto a la Renta. Peru.

Ministerio de Economía y Finanzas. (1 de enero de 2019). Decreto Supremo 339-2018-EF. Peru.

Presidencia de la Republica. (28 de junio de 2012). Decreto Legislativo N 1112 . Peru.

Presidencia de la Republica. (16 de setiembre de 2018). Decreto Legistlativo 1438. Peru.

Presidencia de la Republica. (12 de setiembre de 2018). Decreto Legislativo $N^{\circ} 1425$. Peru.

Resolucion Directoral. (9 de Febrero de 2016). Definiciones Complementarias de la Directiva $\mathrm{N}^{\circ} 002-2016-\mathrm{EF} / 51.01$. 


\section{REFERENCIAS: CASOS}

Casacion, 5476-2016 (Corte Suprema de Justicia de la Republica 6 de octubre de 2017).

RTF, 7969-8-2014 (Tribunal Fiscal 30 de junio de 2014).

RTF, 10313-11-2018 (Tribunal Fiscal 13 de diciembre de 2018).

RTF, 2977-5-2018 (Tribunal Fiscal 19 de abril de 2018).

RTF, 3339-1-2019 (Tribunal Fiscal 5 de abril de 2019).

RTF, 3718-1-2006 (Tribunal Fiscal 2006).

RTF, 4788-2-2018 (Tribunal Fiscal 22 de junio de 2018).

RTF, 919-1-2019 (Tribunal Fiscal 29 de enero de 2019).

RTF, 3925-4-2019 (Tribunal Fiscal 25 de abril de 2019).

RTF, 5020-1-2019 (Tribunal Fiscal 30 de mayo de 2019).

REFERENCIAS: CARTAS E INFORMES DE SUNAT

SUNAT. (2010). Informe Nro. 026-2010/SUNAT/2B0000. Perú.

SUNAT. (2010). Informe Nro. 124-2010-SUNAT/2B0000. Perú. 
SUNAT. (2011). Carta Nº84-2011-SUNAT/200000. Peru.

\section{REFERENCIAS: MARCO CONCEPTUAL Y NORMAS INTERNACIONALES DE INFORMACIÓN FINANCIERA}

Marco Conceptual para la Información Financiera 2018. Recuperado del sitio de internet del Ministerio de Fconomía https://www.mef.gob.pe/contenidos/conta publ/con nor co/vigentes/niif/AnnotatedRB2019 A ES cf.pdf

NIC 2: Inventarios. Recuperado del sitio de internet del Ministerio de Economía y Finanzas:

https://www.mef.gob.pe/contenidos/conta_publ/con_nor_co/vigentes/nic/RedBV2018_IAS02_GVT. pdf

NIC 16: Propiedades, planta y equipo. Recuperado del sitio de internet del Ministerio de Economía y Finanzas:

https://www.mef.gob.pe/contenidos/conta_publ/con_nor_co/vigentes/nic/RedBV2018_IAS1 6_GVT.pdf 